\title{
Article
}

\section{Agile Manufacturing: an evolutionary review of practices}

Angappa, Gunasekaran, Yahaya, Yusuf, Ezekiel, Adeleye, Thanos, Papadopoulos, Dharma, Kovvuri and Dan'Asabe, Geyi

Available at http://clok.uclan.ac.uk/24453/

Angappa, Gunasekaran, Yahaya, Yusuf ORCID: 0000-0001-6045-3245, Ezekiel, Adeleye, Thanos, Papadopoulos, Dharma, Kovvuri ORCID: 0000-0001-92357194 and Dan'Asabe, Geyi (2019) Agile Manufacturing: an evolutionary review of practices. International Journal of Production Research, 57 (15-16). pp. 5154-5174. ISSN 0020-7543

It is advisable to refer to the publisher's version if you intend to cite from the work. http://dx.doi.org/10.1080/00207543.2018.1530478

For more information about UCLan's research in this area go to http://www.uclan.ac.uk/researchgroups/ and search for < name of research Group>.

For information about Research generally at UCLan please go to http://www.uclan.ac.uk/research/

All outputs in CLoK are protected by Intellectual Property Rights law, including Copyright law. Copyright, IPR and Moral Rights for the works on this site are retained by the individual authors and/or other copyright owners. Terms and conditions for use of this material are defined in the policies page.

\section{CLoK}

Central Lancashire online Knowledge www.clok.uclan.ac.uk

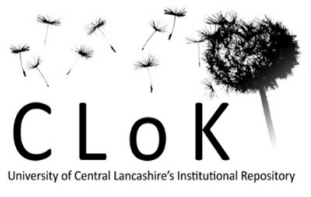




\title{
Agile Manufacturing: an evolutionary review of practices
}

Angappa Gunasekaran ${ }^{1 *}$, Yahaya Y. Yusuf ${ }^{2}$, Ezekiel O. Adeleye ${ }^{3}$, Thanos Papadopoulos ${ }^{4}$ and Dharma Kovvuri ${ }^{2}$ and Dan'Asabe G. Geyi ${ }^{2}$

${ }^{1}$ School of Business and Public Administration, California State University - Bakersfield, 9001

Stockdale Highway, Bakersfield, California 93311-1022, USA

Tel: (661) 654-2184; Fax: (661) 654-2207; E-mail: agunasekaran@,csub.edu

${ }^{*}$ Corresponding Author

${ }^{2}$ Lancashire School of Business and Enterprise, University of Central Lancashire, Preston PR1 2HE, U.K.

${ }^{3}$ Department of Business Administration, Elizade University, P.M.B. 002, Ilara-Mokin, Ondo State, Nigeria

${ }^{4}$ Kent Business School, University of Kent, Sail \& Colour Loft, The Historic Dockyard, ME4 4 TE Chatham, Kent, U.K.

\begin{abstract}
Academics and practitioners have long acknowledged the importance of agile manufacturing and related supply chains in achieving firm sustainable competitiveness. However, limited, if any, research has focused on the evolution of practices within agile manufacturing supply chains and how these are related to competitive performance objectives. To address this gap, we reviewed the literature on agile manufacturing drawing on evolution of manufacturing agility, attributes of agile manufacturing, the drivers of agile manufacturing, and the identification of the enabling competencies deployable for agile manufacturing. Our thesis is that agile manufacturing is at the centre of achieving sustainable competitive advantage, especially in light of current unprecedented market instability coupled with complex customer requirements. In this regard, the emphasis which agile manufacturing places on responsive adaptability would counter the destabilising influence of competitive pressures on organisations performance criteria. We have identified five enabling competencies as the agility enablers and practices of agile manufacturing, that is, transparent customisation, agile supply chains, intelligent automation, total employee empowerment and technology integration, and further explored their joint deployment to create positive multiplier effects. Future research directions were also provided with respect to operationalisation of the five identified enablers and the potential for emergent technologies of big data, blockchain, and Internet of Things to shape future agile manufacturing practices.
\end{abstract}

Keywords: agile manufacturing, supply chains, practices, competitive advantage 


\section{Introduction}

Over the years, companies around the world have been investing resources in improving efficiency, effectiveness and responsiveness of their manufacturing systems, including, for instance, Material Requirement Planning (MRP), and manual engineering techniques such as Total Quality Management (TQM), Just in Time (JIT) and continuous improvement (Inman et al., 2011; Karlsson, 1996; Maskell, 2001; Paranitharan and Jeyathilagar 2017; Yusuf, 1996). However, challenges such as unprecedented instability may threaten the responsiveness of formal planning systems, which rely on historical data and a relatively high degree of market stability. Furthermore, manual engineering techniques such as TQM and JIT systems focused exceedingly on continuous improvement of internal work processes even as external change drivers required an equal amount of emphasis. Therefore, in order to remain competitive, manufacturers have be outward facing and ensure dynamic response to developments in areas such as technology, materials and customer preferences. In this regard, structures and systems for seamless exchange of information and knowledge on replicable designs and world-class competencies are inevitable. Agile manufacturing aims at helping companies to become more competitive and prosperous in challenging environments, where change is unanticipated and continuous (Dowlatshahi and Cao 2006; Gunasekaran, Subramanian, and Papadopoulos, 2017).

The challenge of agile manufacturing design is to put in place structures and systems supportive to the timely delivery of innovative products ahead of competitors (Dubey and Gunasekaran, 2015; Gunasekaran, 1998, Gunasekaran, Subramanian, and Papadopoulos, 2017; Hallgren and Olhanger, 2009; Sharifi and Zhang, 2001; Sindhwani and Malhotra, 2018). Crucial to this challenge is the need to master change through transparent added value to current products and customers as a means of surviving intense competition and market instability (Gilmore and Pine, 1997; Routroy, Potdar, and Shankar, 2015). The manufacturing of a few standard products as in mass production or sequential introduction of families of related products in rapid succession would not guarantee profits and market share (Basu, and Das 2018; Lampel and Mintzberg, 1996; Pine, Victor, and Boynton, 1993). Furthermore, exclusive reliance on continuous improvement and inventory management driven mainly by low cost and level schedule objectives would not achieve significant results (Jonsson and Mattsson, 2008; Lewis, 2000; Power, Sohal, and Rahman, 2001). Although such philosophies and techniques are necessary, they can be inadequate for competing in unstable markets as they can lead to a fragile balance of resource capacities, which cripples robustness to accommodate change and explore windows of temporal opportunities (Aqlan and Al-Fandi, 2018; Bartezzaghi, 1999; Quintana, 1998). 
As a means of remaining competitive, agile manufacturing stresses excellence on a wide range of competitive objectives rather than cost or quality alone. Most importantly, it emphasises being first to market with leading edge customised products, delivered at the cost of mass production. Such products should surpass customer expectations and be able to derail competitors' plans to the extent that the products become change agents. Agility in manufacturing is therefore "the ability to produce a broad range of low cost, high quality products with short lead times in varying lot sizes and built to individual customer specifications" as a means of surviving and prospering in a competitive environment of continuous and unpredictable change" (Fliedner and Vokurka, 1997; Gunasekaran, 1998). As an operations strategy, agile manufacturing can therefore be defined as a business-wide mindset characterised by significant emphasis on routinely adaptable structures and infrastructures and enhanced access to global competencies as a means of achieving greater responsiveness to rapidly changing customer requirements.

Several ideas on the methods and techniques of achieving the goals of agile manufacturing (as aforementioned) are readily available in the literature (Fawcett and Myers, 2001; Gagnon, 1999; Gunasekaran, 1998; Gunasekaran, 1999; Gunasekaran et al., 2018; Oliver, et. al., 1996; Potdar et al., 2017a; Sharifi and Zhang, 2001; Sheridan, 1993). The methods and techniques include mass customisation, supply chain networking, manufacturing automation, employee empowerment and technology utilisation. What remains is to identify deployable best practices for agile manufacturing from the methods and techniques. Before this can be done, current manufacturing practices need to be explored so that bits of agile manufacturing methods and techniques are identified and tested for their individual and collective impacts on competitive and business objectives. Hence, the design challenge is to identify, justify and deploy such methods and techniques.

The overall aim of this review is to revisit agile manufacturing enablers of competitive advantage that can be deployed collectively as a means of remaining competitive and profitable in the increasingly fragmented markets of today that are also characterised by rapid changes. We argue that these enablers are amongst the key resource competencies for enhancing competitive advantage in the rapidly changing global economy (Eckstein et al., 2015; Fawcett and Myers, 2001; Gagnon, 1999; Sheridan, 1993; Wu et al., 2017), and are the building blocks for agile manufacturing. Therefore, the study sets to identify the right mix of enabling competencies for competitive advantage under intensely competitive and unstable markets faced by agile manufacturers. 
The rest of the paper is organized as follows. Firstly, an overview of agile manufacturing is provided including definitions and then the enablers of agile manufacturing are identified and discussed in relation to the achievement of competitive advantage. The paper concludes with a discussion and limitations of agile manufacturing enablers.

\subsection{Agile manufacturing}

The concept of agile manufacturing originated in 1991 from the Agility Forum, a joint initiative of the US government, industry and academics (Ren, Yusuf, and Burns, 2003). The Forum was organised to work out a long-term strategy by which US manufacturers could cope with global competition (Singletary and Winchester, 1998; Thilak, Devadasan, and Sivaram, 2015). The Agility Forum (Gunneson, 1997; Kidd, 1994) defined agility as the ability to thrive and prosper in a competitive environment of continuous and unanticipated change and to respond quickly to rapidly changing markets driven by customer-based valuing of products. Several other definitions abound in the literature but three are stated here (Leite and Braz, 2016; Potdar et al., 2017b; Ramesh and Devadasan, 2007; Thilak, Devadasan, and Sivaram, 2015; Vinodh, Arvind, and Rajanayagam, 2011). The early proponents of agility described it as system with internal resource competencies to answer to customer dynamic demands with speed and flexibility (Yusuf et al., 2014). The firms' internal resources involve both visible and invisible assets (such human resources, information and communications technologies, training and education, highly motivated employees and many others.

Other prior author defined agile manufacturing as follows:

1 "The ability to produce a broad range of low cost, high quality products with short lead times in varying lot sizes and built to individual customer specifications" (Fliedner and Vokurka, 1997).

2 "The capability of an enterprise to survive and prosper in a competitive environment of continuous and unpredictable change by reacting quickly and effectively to changing markets, driven by customer-designed products and services" (Gunasekaran, 1998).

3 "Agility is dynamic, context specific, aggressively change embracing, and growth oriented. It is not about improving efficiency, cutting costs, or battering down the business hatches to ride out fearsome competitiveness storms. It is about succeeding and winning profits, market share and customers in the very centre of competitive storms that many companies now fear" (Goldman, Nagel, and Preiss, 1995) 
These definitions suggest that agility in manufacturing demands an untiring ability to place competitive requirements in context, seize initiatives and invent new product features ahead of competitors (Hasani, Zegordi, and Nikbakhsh, 2012). This is in order to excel on a wide range of competitive and business objectives such as cost, flexibility, product customisation, technology leader, profitability, market share and customer loyalty (Kidd, 1994; Aravind Raj et al., 2013; Wu et al., 2017; Yusuf, Sarhadi, and Gunasekaran, 1999).

The two dimensions of change drivers that often compel the emergence of new systems including agile manufacturing can be categorised into market instability and product complexity. The following discussion further breaks down these dimensions of change drivers in more details. This discussion is in order to identify the drivers of agile manufacturing including competitive pressures in the US where the concept originated.

The US government had a covert military interest in the agile manufacturing campaign, given that the Department of Defence sponsored the Agility Forum. The government was concerned with industrial efficiency and productivity as congress pressured it to award weapons contracts to US manufacturers. This was in addition to concerns for flexibility as defence goods industries converted to commercial production after the cold war (Esmail and Saggu, 1996; Gould, 1997).

In addition to the military interest, the US government and industry were bewildered with a persisting recession, which eventually hit its lowest point in 1991 (Hamel and Prahalad, 1994). Consequently, the Agility Forum stressed the need for US manufacturers, over 60 percent of which were small and medium sized companies, to network capabilities for global competition (Booth and Harmer, 1995; White, Pearson, and Wilson, 1999). In addition, lean techniques such as multiskilling and continuous improvement were deemed inappropriate in the US. Workers deplored practices such as frequent interchange of position, process discipline and never-ending pressures and targets for continuous improvement (Yasin and Wafa, 1996; Young, 1992).

Another driver of agile manufacturing was multiplicity of operations planning and control technologies towards the end of the 1980's and the associated problems over choice and application. By the late 1980s, several manufacturing systems and technologies had evolved, and many had become the popular three letter acronyms such as Materials Requirement Planning (MRP), Total Quality Management (TQM) and Just-In-Time (JIT) (Iqbal et al., 2018; Wallace, 1992). Each of these had become increasing inadequate in addressing the multifaceted challenges 
of manufacturing as companies became confused over choice and application (Aravind Raj et al. 2013). Agile manufacturing would therefore have evolved as an umbrella system that integrates and synthesises preceding systems as a means of delivering on a much wider range of competitive objectives (Brown and Bessant, 2003; Potdar et al., 2017; Sanchez and Nagi, 2001). Such integration provides a means of building a long lasting operations management foundation that would last (Hasani, Zegordi, and Nikbakhsh, 2012; Leite and Braz, 2016).

Apart from the multiple operations planning and control technologies, advances in IT motivated extended enterprise thinking within which companies were to co-operate and operate as seamless chains of resource coalitions for the manufacture of complex products (Brusset, 2016; Theorin et al., 2017).

Largely, the most compelling drivers of agile manufacturing are market instability caused by globalisation, changing customer requirements, product complexity, falling product life cycles, and emergence of best practice (Bartezzaghi, 1999; Dubey and Gunasekaran, 2015; Kidd, 1994; Sanchez and Nagi, 2001).

It follows from the foregoing review that agile manufacturing is not about continuous improvement but about the fundamental re-design of capabilities, systems and processes as a means of advancing simultaneously on a wide range of competitive objectives without significant trade-offs. Nevertheless, for the purpose of this paper looking into articulating agile manufacturing enablers of competitive advantage (Eckstein et al., 2015; Hoek, Harrison, and Christopher, 2001; Sharifi and Zhang, 2001; Sheridan, 1993; Singletary and Winchester, 1998; Wu et al., 2017) the next section explores contingency alternatives on five core dimensions of competence building in manufacturing. This is with a view to identifying and justifying the enablers of competitive advantage within the context of the broader literature on manufacturing and supply chain agility.

\section{Agile manufacturing enablers of competitive advantage}

Agile manufacturing enablers of competitive advantage can be identified from a study of five dimensions of competence building that were most frequently discussed in the literature (Dubey and Gunasekaran, 2015; Gunasekaran, 1998; Gagnon, 1999; Gordon and Sohal, 2001; Fawcett and Myers, 2001; Potdar et al., 2017c; Sharp, Irani, and Desai,1999; Silveira, Fogliatto, and Fendyur 2016; Wu et al., 2017). The five dimensions are mass customisation, supply chain networking, manufacturing automation, employee empowerment and technology utilisation. 
The contingency options on each of the five dimensions of competence building can be tested for harmony with the five principles of agile manufacturing proposed by the Agility Forum (Goldman and Nagel, 1992; Kidd, 1994; Sheridan, 1998). The principles are customer enrichment through mass customisation, enterprise-wide co-operation for enhanced competitiveness, organising to master change through routinely adaptable structures and systems, and leveraging the impact of people, information and technology in order to boost organisational knowledge. Expatiating further on the principles of agile manufacturing, Yusuf, Sarhadi, and Gunasekaran (1999) identified four concepts namely core competence management, virtual enterprise, capacity for reconfiguration, and knowledge driven enterprise. Closely related, Booth and Hammer (1995) specified five generic parameters of a plan for agility. They are organising to thrive on change, leveraging the impact of people and information, devising prompt solutions to customer problems, enterprise-wide co-operation, and integrating social values into decision-making.

The contingency options in competence building can also be tested for compatibility with the engineering and social process requirements specified in the agile manufacturing literature (Deitz, 1995; Gunasekaran, 1998; Lee, 1998). The engineering requirement concerns the design of systems and products (Lee, 1998), whilst the social process prerequisite involves relationships with customers, employees, suppliers and competitors as joint stakeholders in the supply chain (Youssef, 1992). The engineering and social process requirements can be difficult to attain all at once but a balance is essential so that one does not inhibit the other (Tracy et al., 1994). The engineering and social process requirements involve questions pertaining to what product features, by which process, by whom, and where in terms of global manufacturing (Thomke and Reinertsein 1998).

A study of internal and external dimensions of change initiatives also provides a means of identifying agile manufacturing enablers. Internal change initiatives will be agile if they enable internal competition and employee empowerment whilst external change initiatives will be agile as well if they emphasise supply chain development efforts and information networking (Fliedner and Vokurka, 1997). In other words, agile change initiatives should dwell on global networking, collaborative product development, process reconfiguration, and an empowered workforce (Gligor, Holcomb, and Feizabadi 2016; Lee, 2004; Lin, Chiu, and Chu, 2006; Qin and Nembhard, 2010; Swafford, Ghosh, and Murthy, 2008). 
The following sub-sections report contingency practices on each of the five dimensions of competence building in manufacturing. Those practices that bore the greatest resemblance with agile principles and change initiatives as specified in the preceding paragraphs were deciphered as agility enablers of competitive advantage.

\subsection{Mass customisation}

The definition of mass customisation appears to be more common across literature than the definition of agile manufacturing (Brown and Bessant, 2003; Da Silveira, Borenstein, and Fogliatto, 2001; Tu, Vonderembse, and Ragu-Nathan, 2001; Vinodh et al., 2010). Da Silveira, Borenstein, and Fogliatto (2001) argued that mass customisation involves the ability to offer a wide range of products and services variety to every customer at low price. It demands the alliance amongst organisations through agility, flexibility and integrated operations (Liu, Shah, and Schroeder, 2012; Salvador, De Holan, and Piller, 2009). Mass customization is in contrast to mass production, which offers few standard products for everyone (Pine and Davis, 1993), and it differs from lean product development, which upgrades and offers families of related products in rapid chain (Adeleye, Yusuf, and Sivayoganathan, 2000; Power, Sohal, and Rahman, 2001).

Choi and Guo (2018) and Liu, Shah, and Schroeder (2012) identified mass customisation as an important strategy for enterprises to enhance competitive advantages in dynamic and uncertain marketplace. Mass customisation preceded agile manufacturing. Following Zhang et al. (2015); Huang, Kristal, and Schroeder (2008); Tu et al. (2004) among others, contended that mass customisation entails the capability to swiftly design, produce and deliver high volume of different products that meet specific customer demands. Rungtusanatham and Salvador (2008) maintained that the adoption of mass customisation calls for the redefinition of business strategies and processes in order to create flexible automation and process modularity (Salvador, De Holan, and Piller, 2009).

Therefore, this notion relates to 'market sensitivity', which aimed at delivering personalised products at competitive cost (Duray, 2002; Silveira, Fogliatto, and Fendyur, 2016). In the same token, Squire et al. (2004) and Merle et al. (2010) argued that mass customisation provides superior value by enabling customer to elect and often co-design products including unique specifications. Literature (Choi and Guo 2018; Da Silveira, Borenstein, and Fogliatto, 2001; Jitpaiboon et al., 2013; Tu et al., 2004; Trentin, Forza, and Perin, 2012; Wang, Wang, and Zhao, 2015; Zhang et al., 
2015; Zhang, Qi, and Guo 2017) established that advanced IT, computer aided design, and product modularity enable companies to deliver customised products through integrated operations.

Accordingly, several studies have acknowledged the success of mass customisation paradigm in industries (Alford, Sackett, and Nelder, 2000; Fawcett and Myers, 2001), whereas other studies have explored the success of mass customisation in the telecommunication industry (Sigala, 2006), construction (Barlow et al 2003), and biomedical components (McMains, 2005; Pallari, Dalgarno, and Woodburn 2010), fashion (Choi and Guo, 2017), and more recent studies have linked mass customisation to supply chain integration and product modularity (Zhang et al., 2017a).

As a result, the progress of mass customisation from a niche approach to become generally accepted business strategy (Matzler, Stieger, and Füller, 2011; Thilak, Devadasan, and Sivaram, 2015). Perhaps because of the increasing customer demand for customised products and services (Ahmad, Schroeder, and Mallick, 2010), new information technology providing innovative codesign (Jitpaiboon et al., 2013; Ong et al., 2006), and transparent transfer of knowledge using computer aided design (Wang, Wang, and Zhao, 2015; Zhang et al., 2017b). Consequently, numerous studies have conceptualised mass customisation, ranging from pure standardisation to pure customisation (Da Silveira, Borenstein, and Fogliatto, 2001; Lampel and Mintzberg, 1996; Shukla, Todorov, and Kapletia, 2018).

Da Silveira, Borenstein, and Fogliatto (2001) suggested a range of eight levels of customisation. These are fabrication, process designed, assembling modular components, different package and distribution, adapted products, additional custom work and services as well as no product variances. Spira (1993) argued that there are four levels of mass customisation including customised service, modular assembly, customised packaging and additional custom work. By the same token, Gilmore and Pine (1997) developed four faces of mass customisation as contingency alternatives. These include cosmetic, collaborative, adaptive and transparent. At the extreme end of pure standardisation, little or none of the operations of design, fabrication, assembly and distribution is customised, whereas they are all customised at the other extreme of pure or transparent customisation, where every product solution tends to be technically unique. Cosmetic customisation differentiates mainly on packaging and appearance as a means of making standard products appear differentiated in the eyes of customers. Cosmetic customisation is also useful in differentiates packaging quality and targeting them to a range of income groups. 
Cosmetic customisation as explained in the preceding paragraph will be inconsistent with transparent customisation as a concerted strategy of survival in markets characterised by changing and complex customer requirements (Fawcett and Myers, 2001). As a contingency option in mass customisation, transparent customisation is more close-knit to the expectations of the literature of agile manufacturing. This is in terms of accommodating to changing customer requirements through customer-led product solutions. Nevertheless, the resource capabilities required for transparent customisation are beyond single companies but within the reach of networked companies operating as virtual resource coalitions (Lee and Lau, 1999; Perry and Sohal, 2001). For this reason, a discussion of supply network follows as the second element of industrial capability building from which agility enablers can be identified.

\subsection{Supply chain networking}

The development and manufacturing of customised products often dependent upon strong collaboration with suppliers and customers (Trentin, Forza, and Perin, 2012). A number of studies have demonstrated that the outdated supply chain no longer worked very well (Christopher, 2000; Harrison et al., 2014; Mentzer et al., 2001). It will be apparent that the traditional arm's-length and buyer/supplier relationships required a significant change (Christopher, 2016). Accordingly, supply chain management involve the management of upstream and downstream relationships with suppliers and customers to deliver superior customer value at less cost to the supply chain as a whole. This predicted upon dynamic leadership of cooperation and trust in order to realise competitiveness for entire chain partners.

Nevertheless, the key threat to this form of traditional relationship was that the self-interest of one participant may be subsumed for the benefit of the entire chain. Aitken, Christopher, and Towill (2002) pointed out that supply chain involve a network of connected and interdependent organisations mutually and cooperatively working together to control, manage and improve the flow of materials and information from suppliers to end users. In line with this notion, Christopher (2016) maintained that the market should drives the chain, not the suppliers. The author added that it would be more appropriate to replace the word 'chain' with 'network' as there may be multiple suppliers and indeed, suppliers to suppliers as well as multiple customers and customers' customers within the aggregate supply chain.

Thus, this form of co-operative relationships has become crucial in mobilising resource capabilities across company boundaries and delivering superior solutions ahead of competitors (Christopher, 
2016; Harrison et al., 2014). Collaborative networked enterprises encompass networks of largely autonomous industries, geographically distributed and heterogeneous cooperating to better achieve shared goals through internet to support communications (Arrais-Castro et al., 2018; Camarinha-Matos et al., 2013).

Supply chain network preceded agile manufacturing. Researchers such as Trentin, Forza, and Perin (2012), and previously Mikkola and Skjott-Larsen (2004) and Salvador Rungtusanatham, and Forza (2004) highlighted that made-to-order products require more integrated supply chain structures. Nevertheless, a number of researchers highlighted supply chain collaboration as element of agile enterprises, because agile design and manufacturing focuses upon the strength and capabilities of network partners (Chen and Paulraj, 2004; Dyer and Singh, 1998; Lai et al., 2012).

In addition, agile manufacturing involves a series of capabilities and practices that are more accomplished using alliance with supply network partners (Sindhwani and Malhotra, 2018). The unanticipated changes in customer demands and design specifications requires intensive sharing of information across the supply chain to facilitate new product and process development (Fridgen, Stepanek, and Wolf, 2015; Trentin, Forza, and Perin, 2012). This knowledge is often transferred through virtual partnerships (Chen, Chiang, and Storey, 2012; Peng, Liu, and Heim, 2011; Tseng, Chang, and Chen, 2012), which may facilitate network enterprises to allocate core modules of production amongst themselves, based on the strength and relative competencies (Lee and Lau, 1999; Venkatraman and Henderson, 1998).

Several factors motivate supply chain networking. The first is advances in information and Internet technologies, which enable mutual and real time access to information, data and files amongst companies spatially distributed across the globe (Arampantzi, Minis, and Dikas, 2018; Ghobakhloo, Hong, and Standing 2014; Kache and Seuring, 2017). Although IT applications initially evolved to support secure and evidential transfers of trading reports, cash and other assets and obligations by multi-national companies, applications have extended to logistics management, design, scheduling and manufacture (Gunasekaran, Subramanian, and Papadopoulos, 2017; Han, Wang, and Naim, 2017; Jayaraman, Ross, and Agarwal, 2008, Soliman and Youssef, 2001).

Secondly, the advent of Just-In-Time practices with emphasis on smaller volumes of transactions motivates supply chain networking (Mo and Cook, 2018). This is because of the need to monitor real-time and as an integrated routine process, the volumes of transactions that were specified, executed and delivered. In addition, efforts to widen the range of product options available to 
customers motivated manufacturers to seek direct linkage to customers as well as direct control and sometimes part ownership of suppliers and distributors (Lapoule and Colla, 2016; Lehoux, D'Amours, and Langevin, 2014).

The third motivator of supply chain networking is product complexity, which compels focusing strategies (Jacobs, 2013). As products and customer specifications become more complex, companies strive to focus on only a narrow aspect of the total supply chain where competitive advantage is greatest whilst networking with other companies to complete the supply chain (Christopher, 2016). This requires that companies work with equal vigour and commitment to add the greatest values (Blome, Schoenherr, and Eckstein, 2014; Coronado Mondragon and Coronado Mondragon, 2018; Hu et al., 2008; Inman and Blumenfeld, 2014).

Knowledge Transfer on critical competences in design and manufacturing has become a vital tool of competition (Jayaram and Pathak, 2013; Mountney, Gao, and Wiseall, 2007). Hence, entire supply chains rather than individual companies are emerging as the unit of analysis in the new competitive game plan. Success in the new competitive game plan required that companies' surrender their capabilities to their supply chains and become connected to the global resource base through modern IT (Singh and Power, 2014). Networking promotes shared understandings, employee awareness and tracking of customer expectations. It also reduces errors and time cycles in product and process development efforts (Cai et al., 2013; Perry and Sohal, 2001).

Conceptually, a range of contingency models in supply chain networking can be identified. They include strategic alliances employed for market penetration by global conglomerates, lean supply chains for outsourcing and distribution as a means of ensuring a level schedule, and agile supply chains renowned for global leverage of manufacturing competencies (Boardman and Clegg, 2001; Christopher and Towill, 2001; Prater, Biehl, and Smith 2001).

Several companies adopted the model of supply chain as an important determinant of competitive advantage. This is because it influences access to real time data and knowledge, and the attendant ease of mobilising global resources to tap temporal windows of opportunities (Hoek, Harrison, and Christopher, 2001; Kehoe and Boughton, 2001; Mason-Jones, Naylor, and Towill, 2000; Power, Sohal, and Rahman, 2001; Yusuf, Adeleye, and Sivayoganathan, 2001). 
The lean supply chain as supposed in several works is the most dominant form of supply chain networking in the literature (Jasti and Kodali, 2015; Marodin et al., 2017; Van Riet, De Clerck, and Demeulemeester 2015; Soni and Kodali 2016). More suitable in a relatively stable market, the lean supply chain emphasises long-term contracts for outsourcing and distribution, with a view to secure cost and quality gains whilst also committing suppliers and customers to planned JIT supplies and schedules (Agarwal, Shankar, and Tiwari, 2006; Christopher and Towill, 2001; Goldsby, Griffis, and Roath, 2006; Kisperska-Moron and De Haan, 2011; Naim and Gosling, 2011; Naylor, Naim and Berry, 1999). In order to facilitate these objectives, inspection, coaching and financial support for suppliers and distributors were popular (Agarwal, Shankar, and Tawari, 2006; Wagner and Silveira-Camargos 2012; Wee and Wu, 2009; Yusuf et al., 2004). However, manufacturing process dependency, opportunistic collaboration and virtual integration as a means of exploring temporal opportunities are limited (Hoek, Harrison, and Christopher, 2001; MasonJones, Naylor, and Towill, 2000; Power, Sohal, and Rahman, 2001).

Accordingly, the agile supply chain is underpinned by global exchange of manufacturing competencies through the Internet (Dubey et al., 2018). It enables timely mobilisation of worldclass resources as a means of responding to emerging customer expectations ahead of the competition (Boardman and Clegg, 2001; Christopher and Towill, 2001; Goldman, Nagel, and Preiss, 1995; Perry and Sohal, 2001). In this regard, the agile supply chain is nearer to the expectations of agile manufacturing in terms of delivering transparently personalised products ahead of competitors and at the cost of mass production. In the light of unprecedented market instability and product complexity, the agile supply chain has the potential to enhance attainment of a wide range of competitive and business performance criteria (Blome, Schoenherr, and Rexhausen, 2013; Dubey et al., 2018; Eckstein et al., 2015; Hoek, Harrison, and Christopher, 2001; Martinez-Sanchez and Lahoz-Leo 2018; Tarafdar and Qrunfleh, 2017; Power et. al., 2001).

Whereas until recently supply chain networking refers almost exclusively to long-term supplier relationships, an equal amount of downstream collaboration with customers and lateral cooperation with competitors has become increasingly important (Christopher and Towill, 2001; Hoek, Harrison, and Christopher, 2001; Saban et al., 2017; Power, Sohal, and Rahman, 2001; Saban, Mawhinney, and Drake, 2017). Indeed, an agile supply chain should integrate the entire gamut of manufacturing and logistics operations into a seamless flow (Kim and Chai, 2017). Supply chain agility can therefore be explained as a measure of the extent to which the entire gamut of upstream and downstream operations is integrated and supportive of the following pivotal objectives of agile manufacturing (Alfalla-Luque, Machuca, and Marin-Garcia, 2018; Chiang, 
Kocabasoglu-Hillmer, and Suresh, 2012; Hoek, Harrison, and Christopher 2001; Kehoe and Boughton, 2001).

\subsubsection{Agile supply chains}

Agile supply chains consist legally separate and spatially distributed companies engaging in collaborative design and manufacture, with the aid of Internet-based information technologies (Braunscheidel and Suresh, 2009; Christopher and Towill, 2001; Gunasekaran and Ngai, 2004; Shaw et al., 2005). It was also considered as an extension of agile manufacturing (Brown and Bessant, 2003; Dwayne Whitten, Green, and Zelbst, 2012). Blome, Schoenherr, and Rexhausen (2013) argued that supply chain agility encompass the enterprises' capability to respond to change in market environment characterised with variation in terms of shortages and disruptions. As Swafford, Ghosh, and Murthy (2006) maintained, supply chain agility assist an organisation to quickly respond to marketplace volatility and other uncertainties, thus support the company to create a greater competitiveness (Dwayne Whitten, Green, and Zelbst, 2012). Besides, organisations with agile supply chain capabilities are more customer sensitive, better capable of blending supply with demand and able to achieve shorter cycle times. According to several authors (Braunscheidel and Suresh, 2009; Dubey et al., 2018; Eckstein et al. 2015; Gligor and Holcomb, 2014; Tarafdar and Qrunfleh, 2017), supply chain agility as an essential capability required to sustain and thrive in a volatile marketplace. As such, agility facilitates fast and adaptable response (Gligor and Holcomb, 2012), and considered to extend the narrower notion of supply chain flexibility (Stevenson and Spring, 2007). Similarly, Blome, Schoenherr, and Rexhausen (2013) argued that supply chain agility entails a dynamic capability, which underpins and enhances the operational performance of organisations. For this reason, we argue that supply chain agility is a necessary condition to achieve agile manufacturing.

Furthermore, agility capability can be measured based on interdependent dimensions of supply chain maturity such as interfirm partnerships, complementary resources competencies, knowledge transfer and effective leaderships (Braunscheidel and Suresh, 2009; Venkatraman and Henderson, 1998). However, the challenge of an agile enterprises would be to improve and ensure balance across the symbiotic dimensions shown in Column 1 of Figure 1 below. Relative scores on the three dimensions provide a basis for testing maturity towards agile supply chains. 


Anywhere
Customers
Company
Departmental
Division

Figure 1. Reach and Range analysis of supply chain, integration (Browne, Sackett, and Wortmann, 1995).

In addition, the nature of an agile supply chain can be analysed in terms of the reach and range of activities covered by networking (Kehoe \& Boughton, 2001; Yusuf et al., 2004). Figure 1 illustrates the reach and range approach. On the vertical axis, information reach extends from personal to anywhere whilst on the horizontal axis, the range of activities widens from electronic messaging to Internet-based integration. Accordingly, as shown in Figure 1, supply chain agility increases as the degree of freedom in networking widens from bill of material controls to purchasing efficiency and to demand and capacity planning.

As such, customer interaction involves reaching out to spatially distributed customers, working with customers towards dynamic customisation for clusters of unique preferences and establishing communities of customers. At the highest level of customer interaction, a company owns customer communities as a means of making transparent customisation more sustainable. This is due to the advantages of customer-inputs to product upgrades rather than seeking variety as an end in itself. In addition, there are potential benefits of market concentration in terms of getting unique customer communities committed to long-term contracts of supply, which are called off in small volumes over time (Wu et al., 2017). Indeed, the incidence and destructive impacts of the "Forrester's effect" can be minimised (Chandra and Kumar, 2000). Without close interaction with 
customers, mismatches between production volume/ mix and customer expectations often arise, and however marginal, they potentially cause panic and speculation up and down the supply chain. The attendant consequence is that production plans and schedules are based on false and distorted market data, which causes another round of mismatch that is bigger in magnitude and accelerating the initial effect.

Accordingly, there are four dimensions of agile supply chain practices (Christopher, 2016; Hoek, Harrison, and Christopher, 2001; Power, Sohal, and Rahman, 2001; Tsanos, Zografos, and Harrison, 2014). These are: Customer sensitivity; virtual integration, process integration and network integration. Customer sensitivity, on the one hand, obliges quick response to customer requirements while network integration requires that companies in the supply chain have a common identity, which can range from commitment to agile practices, compatibility of structure, compatibility of information architecture and collaborative competencies. Furthermore, virtual integration requires that companies trade more in information and knowledge sharing rather than inventories, and surrender to the Internet, all knowledge and competencies, which remain largely protected (Kim and Chai, 2017).

Lastly, process integration suggests that networking companies delegate core modules of production amongst themselves based on their relative competencies. This requirement of process integration differs from contract manufacturing, which can potentially increase cost through hierarchies of non-value-added commercial margins. Therefore, an agile supply chain should embody the four elements of supply chain networking. However, the virtual element, which is perhaps the greatest innovation in agile manufacturing, is largely absent in most supply chains (Christopher and Towill, 2001; Christopher, 2016; Harrison et al., 2014; Hoek, Harrison, and Christopher, 2001; Martinez-Sanchez and Lahoz-Leo, 2018; Power, Sohal, and Rahman, 2001).

In general, customer sensitivity means that supply chain networking initiatives should enable quick response to customer requirements based on point of sale data capture and transmission. To this end, manufacturing processes require integration and specialisation based on relative core competencies of networking companies. The element of network integration requires that companies operate as confederation of partners equally committed to agile practices as a means of leveraging competencies for leading and transparent customisation of products. The fourth element, which is virtual integration, goes beyond network integration and demands that companies surrender to the Internet all knowledge and competencies, which remained largely 
protected. Three out of the four elements are concerned with integration as a means of aiding customer sensitivity, which is the fourth element. The foregoing discussion signifies that an agile supply chain is integrated, and this integration is facilitated by ICTs (Christopher and Towill, 2001; Shamsuzzoha and Helo, 2018; Theorin et al., 2017).

Crucial to the agile supply chain are multi-level teams of local and remotely distributed workers, who interact, conceive and commit their companies to temporal opportunities without the luxury of waiting for inhibiting approvals from superior personnel. Such employees would require empowerment through training, teaming and re-orientation towards reliance on peer consensus rather than superior authority. Following next is a discussion of employee empowerment as the third dimension of competence building in manufacturing from which agility enablers can be identified.

\subsection{Employee empowerment}

The people working in the organisations play an important role in the way enterprises create and capture value to the customers. The literature on agile manufacturing (Gunasekaran and Yusuf, 2002; Hasani, Zegordi, and Nikbakhsh 2012; Potdar et al., 2017c; Aravind Raj et al., 2013; Sharp, Irani, and Desai 1999), lean production (Jasti and Kodali, 2015; Marodin and Saurin, 2015; Netland, 2016; Tortorella et al., 2015) and other related studies (Fawcett and Myers, 2001; Plonka, 1997; Forsythe and Ashby, 1996) agreed that employee empowerment is crucial for companies in unstable markets. The consensus is that companies change from vertical to horizontal structures in which consensus among professionals and work groups become superior to formal authority (Quinn, 1992). A lateral organisation empowers professionals and shop floor employees. It also potentially halts the separation of doers from thinkers whilst minimising several divisive interfaces that polarises structures, depletes resources and inhibits timely response (Gunneson, 1997). Employee empowerment therefore requires a complete realignment of power relations within which managers emphasise interdisciplinary collaboration and leadership, shared values and motivation for knowledge diversity (Fawcett and Myers, 2001; Forsythe, 1997).

Empowerment can be discussed from three main dimensions. They are training that targets work content improvement and teaming that fosters joint authority and responsibility for decisions and actions in work groups (Forsythe, 1997; Gunasekaran and Yusuf, 2002; Kidd, 1994; Sanchez and Nagi, 2001). The third is involvement in decision-making including methods of work and motivation as well as determination of remuneration and other perquisites (Maskell, 2001). The 
training dimension also requires providing workers with appropriate knowledge, skills and tools necessary to manipulate and operate intelligent machines and technologies. This is in addition to putting in place concurrent engineering structures that enable employees to operate in selfdirecting, self-communicating and self-organising teams. Furthermore, empowerment suggests that workers are able to influence decisions about their job performance, work environment and company's future (Iqbal, Huq, and Bhutta 2018; Marodin and Saurin, 2013).

The ease of realigning power relations within existing organisation structures as well as the relative efficacy of decision-making based on peer consensus and position-power under situations of sporadic change is dicey. However, employee empowerment has been proposed as the principal assets in making a plant truly flexible, notwithstanding loads of intelligence possessed by advanced manufacturing systems (Upton, 1995; Pinochet et al., 1996). For workers to perform effectively, a considerable amount of training and retraining is required in areas (Iqbal, Huq, and Bhutta, 2018; Netland, 2016; Potdar et al., 2017c) such as managing shared resources for productivity and reusability, interpersonal skills for teaming and peer leadership, information science and proficiency in applications software, systems orientation that emphasises the global impact of local decisions and actions, technology evaluation, utilisation and troubleshooting, multi- skilling especially in operations before and after own workbench, and problem-solving skills.

Team practices and dispositions facilitate job assignment, execution and delivery because they support parallel and integrative conduct of activities involved in design, engineering and manufacture (Forsythe, 1997; Gadient et. al., 1997; Goldman and Nagel, 1992; Iqbal, Huq, and Bhutta, 2018). A team culture would be easier to nurture in a plant that has embraced teaming as an organisation system underpinned by the principles of multi-dimensional collaboration that is inherent in concurrent engineering (Bortolotti, Boscari, and Danese, 2015; Fawcett and Myers, 2001; Shah and Ward, 2007; Yusuf et al., 2014; Zhang, 2011). A team-based concurrent engineering structure empowers employees individually and collectively, and therefore enhances the knowledge base available for profitable and sustainable mass customisation (Narasimhan, Swink, and Kim, 2006; Yang, 2014). Moreover, most operations will be run as mini-companies, each with its own sense of identity and loyalty (Castellano et al., 1999; Gunasekaran and Yusuf, 2002). Accordingly, smaller groups of employees will be responsible for resources and results, and management attention would shift from individual or functional work units to project teams. 
In industries faced by unprecedented market instability and product complexity, teams of empowered employees will be indispensable in servicing agile supply chains and mobilising global competencies (Yan and Jiang, 1999). Nevertheless, reports abound that team practices in lean production have become unwieldy, exploitative and punitive due to significant emphasis on heavyweight leadership, seniority-based pay, peer-surveillance and unending pressures for continuous improvement. In this context, teaming perhaps strip workers of their personal rights, specialist skills and autonomy rather than empower them (Forza, 1996; Karlsson, and Ahlstrom 1996; Young, 1992; Warkentin, Sayeed, and Hightower 1997). The aforementioned problems are avoidable in agile plants where operations are more decentralised and less line oriented. Instead, operations are project and niche market-based and also virtual in character (Forsythe, 1997; Henry, 1998; Saraph and Sebastian, 1992; Yang and Lee, 1996; Warkentin, Sayeed, and Hightower 1997).

In addition to training and teaming, employee involvement is another important dimension of empowerment. It manifests itself in several ways including, for instance, stoppage of production flow on observation of any anomalies, adaptation of work teams to variations in job duties and in the production flow, commitment to continuous improvement and innovation through exchange of knowledge and improvement suggestions, and better opportunities to influence top management decisions (Sanchez and Nagi, 2001; Sumukadas and Sawhney, 2004; Zhang, 2011). Accordingly, empowered employees are the principal assets in the agile factory (Fawcett and Myers, 2001; Raj et al., 2013; Vinodh, Madhyasta, and Praveen, 2012). They are the core enablers of competitive advantage as advances in technology and best practices transform job structures and extend workers' scope of discretion and responsibility (DeGroote and Marx, 2013; MacDonald and She, 2015; van Hoof and Thiell, 2014). For these reasons, a wide range of training programmes especially in operations before and after own workstation, technology application, system monitoring, and cooperative ethics are imperative (Fawcett and Myers, 2001; Goldman and Nagel, 1992; Zhang, 2011).

The relative emphasis placed on each of training, teaming, involvement and commitment as dimensions of employee empowerment and as determinants of agile competitive advantage would differ widely in practice. Empowerment scores could be insignificant for all the four dimensions, higher for only one or two dimensions or substantial for all the four dimensions. In order to cope effectively with the challenge of change as well as marshal the skills required to operate intelligent machines and deliver transparently customised solutions ahead of competitors, empowerment should be multi-dimensional and total. Therefore, maximum deployment of employees' knowledge 
capabilities is crucial as a means of boosting the ability to manipulate intelligent machines (Blome, Schoenherr, and Eckstein, 2014; Fawcett and Myers, 2001; Li et al., 2008). Following next is a discussion of manufacturing automation as the fourth dimension of manufacturing competence building from which agility enablers can be identified.

\subsection{Manufacturing automation}

Modern manufacturing technologies such as automation, robotics and other practices are now used globally following the progress in information and communication technologies and internationalisation of supply chain (Caggiano and Teti, 2018; Lau et al., 2002). Manufacturing automation refers to the total gamut of operations, which can be performed by plants and equipment with minimal human intervention (Pinochet, Matsubara, and Nagamachi, 1996). The pervasive computing, advanced software and sensor technologies have enhanced capability and reliability of manufacturing systems by reducing costs and creating products using low energy, low resources input, eliminate human error and quickly responding to customer demands for high quality, customisation or personalisation, reducing time to market, and product delivery time as well as increasing complementary of services (Edwards, 1996).

More so, the deployment of automate human processes, information and communication technologies is now used to facilitate integration of data across business processes. This will improve customer relationships management, process control, products verification, manufacturing simulation, logistics, safety systems and product traceability as well creating new ways to involved customers into design and suppliers into complex production processes. Recently, this notion has resulted in the development of big data, cloud computing and the internet of things (Gunasekaran et al., 2018).

However, based on the level of human intervention required by a machine and the range of operations that a machine can be manipulated to execute, three contingency alternatives in manufacturing automation can be identified. They are mass automation, flexible automation, and intelligent automation (Bodine, 1998; Kirk and Tebaldi, 1997; Kusiak and He, 1997). In mass automation, machines had been in-built to perform specific operations and cannot be altered, retooled or re-programmed to do anything else. On the other hand, flexible automation has an advantage of being adaptable and able to perform a wider range of operations, although valuable time is spent to retool and change over. 
Despite the benefits of flexible automation, it is may not be suitable for relatively simple machining and assembly tasks especially in high volume repetitive batch processes rather than for continuous reconfiguration and customisation of products (Kusiak and He, 1997). Intelligent automation is largely computer-controlled, with closed-loop feedback systems and in-built diagnostic capability (Waters, 1996). They operate as integrated but independent networks of computer numerically controlled $(\mathrm{CNC})$ machines, feeders, controllers, actuators and sensors connected by conveyors (Bodine, 1998; Kusiak and He, 1997; Lee, et al., 1997). Supported by advanced network communications and distributed computer systems, they can be programmed to conduct a wide range of machining and assembly tasks without the time and effort entailed in flexible manufacturing systems. Intelligence and mobility are crucial for speedy customisation and replication of the core modules of intelligent products at little or no extra cost (Kusiak and He, 1997; Zammuto and O'Connor, 1992; Zhang and Zhang, 1995).

In the light of shrinking life cycles and intense mass customisation that tend to fragment and reduce order quantities and life cycle profits, intelligent and versatile machines are the strength of the agile factory. This is because reproduction costs of products manufactured by intelligent machines are not volume sensitive (Ramesh, Jyothirmai, and Lavanya, 2013). Intelligent automation requires a strategy in order to enhance its adoption (Iakymenko, Alfnes, and Thomassen, 2016; Kirk and Tebaldi, 1997; Molina et al., 2005). Firstly, the goal of intelligent automation is dynamic reconfiguration as a means of responding to changing specifications and achieving mass customisation at the cost of mass production (Molina et al., 2005; Phaithoonbuathong et al., 2010; Renna and Ambrico, 2015; Willis, 1998). Another element of automation strategy is that intelligent automation requires a considerable amount of knowledge work especially in re-programming machines for several one of a kind production situation (Bhuiyan, Baghel, and Wilson, 2006; Dailami and Redford, 1998; Kirk and Tebaldi, 1997; Pullan, Bhasi, and Madhu, 2010). This is unlike traditional automation of repetitive processes where knowledge work is not significant (Bodine, 1998; Hines, Taylor, and Walsh, 2018; Kusiak, 2018). Finally, advances towards intelligent automation can be in discreet steps. The most basic step is cellular layout of machines based on related jobs or parts families (Shiyas and Madhusudanan Pillai 2014; Pillai and Subbarao, 2008). A cell generally consists of one or two stand-alone CNC machines, complemented by ancillary equipment such as robotic parts handlers (Ahkioon, Bulgak, and Bektas, 2009; Lau, Mak, and Ngan, 2002). Once a cellular design has been implemented, a range of simple machining and assembly tasks can be automated selectively based on the exact needs of individual cells (Alhourani, 2016; Bodine, 1998). Therefore, the range and intensity of 
automation, flexibility, machine intelligence and operational mobility in material handling would vary across cells.

The impacts of cellular design on competitive advantage have been demonstrated (Brussel et al., 1999; Chambers and Nicholson, 2000; Wu et al., 2006). Cellular design leads to smaller worksystems to which employees are more committed (Pillai and Subbarao, 2008). It also promotes interaction amongst equipment, workstations and product modules, with attendant improvement in ability to trap problems at source, conduct parallel operations and flex capacity (Brussel et al., 1999; Groover, 2007; Wu et al., 2006).

The foregoing discussion reveals that manufacturing automation influences competitive advantage. Three contingency options in manufacturing automation were discussed in the preceding paragraphs out of which intelligent automation appeared more suitable for plants engaging in transparent customisation. This discussion of intelligent automation as an agility enabler revealed five core elements, which are cellular design, a wider range of automated processes, machine flexibility, machine intelligence and plant mobility.

\subsection{Technology adoption}

Companies adopt and learn incrementally from a wide range of technologies as a means of enhancing competitive advantage (Bello-Pintado, García Marco, and Zouaghi, 2018; Borges and Tan, 2017; Cozzarin, 2016; Khanchanapong et al., 2014; Kotha and Swamidass, 2000; Soliman, Clegg, and Tantoush, 2001). Technology integration, in terms of "modular integration" and "assimilation of lessons learnt" in a wide range of emerging technologies such as MRP, JIT, TQM, $\mathrm{CE}$ and OPT was proposed as a core enabler of agile competitive advantage (Singletary and Winchester, 1998; Sousa and Voss, 2008). Therefore, towards agile manufacturing design, intelligent synthesis of tools and methods are essential for competing and satisfying customers' requirements from all fronts. However, several companies perceive technologies as alternatives even as joint deployment could be a complex process (Youssef, 1992; Zhang et al., 2015), no matter if they can boost process capabilities for speedy customisation and delivery of advanced product solutions (Youssef, 1992; Soliman, Clegg, and Tantoush, 2001).

Several researchers have articulated adoption or synthesis of multiple technologies as an essential requirement of agile manufacturing design (Dowlatshahi and Cao 2006; Dubey and Gunasekaran 2015; Gunasekaran 1999; Kang et al., 2016; Yusuf, Sarhadi, and Gunasekaran, 1999 Zhang et al., 
2014). Indeed, multiplicity of operations techniques by the late 1980's (Aggarwal, 1985; Wallace, 1992) could have motivated the emphasis placed by the agility movement on synthesis of technology. As managers in the past were sceptical over choice and application of technology (Wallace, 1992), it was crucial to connect and learn incrementally from the range of available options (Goldman, Nagel, and Preiss 1995; Harrison and Storey, 1996). In this sense, agile manufacturing supports systematic learning and mastery of several techniques of lean production and concurrent engineering and the lessons they offered (Goldman and Nagel, 1992; Gunneson, 1997). The synthesis of several technologies is imperative for systematic and co-ordinated response to market instability (Singletary and Winchester, 1998). In a recent study, Dubey and Gunasekaran (2015) highlighted the contribution of IT in technologies that enable information to be shared effectively and efficiently, whereas Gunasekaran, Subramanian, and Papadopoulos (2017) had looked at the role of big data within agile manufacturing, especially in addressing market turbulence and helping companies to remain competitive and achieve their business performance objectives.

Deciding what technologies are appropriate would depend on contextual factors including, for instance, location, industry, size, technology, strategy, resource capabilities and goals (Spina et al., 1996). The range of technologies adopted and implemented will therefore be determined by the relative importance and relevance of competitive objectives in different situations and times (Sohal et al., 2006; Vokurka and Fliedner, 1998).

In general, advances in ICTs have significantly facilitated the development and application of operations, intensity of customisation and depth of supply chain integration (Monostori et al., 2016; Smit et al., 2016; Shariatzadeh et al., 2016). However, adaptation, compatibility, and security problems the use of IT for agile manufacturing (Davenport, 1998; Gadient et al. 1997; Liu et al., 2013; Macke, Rulhoff, and Stjepandic, 2016; Tse et al., 2016). However, we argue that integration still enhances the ability to devise and deliver integration as a means of surviving market instability.

\section{Critique of agile manufacturing}

A number of studies on agile manufacturing are optimistic in term of the achievement of outcomes. But there have been multiple threats current facing manufacturing. One of the major issues are social and environmental aspects (Ciccullo et al., 2017; Gunasekaran et al., 2018). Organisations are currently seeking new ways to integrate social and environmental practices with agile or virtual integration operations to create unique capabilities to improve their sustainable competitiveness. However, the traditional metrics used to measure performance objectives of 
costs, speed, quality, flexibility, dependability and innovation are no longer sufficient (Searcy, 2012). There now a needed for companies to deliver on sustainability performance. These would be vital in illuminating major interconnections across industry, expounding the essential role of production processes in the supply network as well as assisting to ascertain, which practices in the value chain needs intervention and to support network partners as they focus on creating new and extra benefits. Thus, sustainable manufacturing means inclusive production, which encompasses three perspectives (such as, people-oriented, environment-oriented, and technology-oriented innovations.

Another threat is increasingly dependent on highly skilled workers (Dubey and Gunasekaran, 2015). Manufacturing is no longer about making a product and selling it. But it placed greater importance on using new sources of knowledge and information and establishing much closer, long-term relationships with suppliers and customers as well as other stakeholders. Effective company would harness a wider skills base; by including all categories of people in different manufacturing activities irrespective age, gender and social status to improve the skill set of future workforces. More so an increasing emphasis on intelligent and sustainable product also threatens agile manufacturing. Accordingly, firms are encouraging to recognise product life cycle and safe handling of end of life products. Products and processes would be sustainable with built-in reuse, remanufacturing and recycling for products reaching, closed loop supply chain can be employed to eliminate excessive energy and water waste and recycle physical waste. These developments will further emphasis the key role of physical production in unlocking sustainability performance of the organisation, particularly as supply chain focus on offering quality of services (servitisation) and make use of the increasing pervasiveness of Big data, cloud computing and internet of things to enhance their overall performance (Gunasekaran, Subramanian, and Papadopoulos, 2017; Kim and Chai, 2017).

Another challenge is that the manufacturing policy need to consider the extended nature of value chain and the new way to develop such strategy. Some companies have already familiarising and are world class, but many are not positioned to succeed in a future world where the greater opportunities would be balanced through greater competition. The manufacturing need to be sustainable, agile, adaptive, and virtual to radically redefine its strategy to offers a constant and consistent framework in which supply network partners aspire to flourish. However, an organisation with rigid strategy may not deliver that sustainable competitiveness. Although, a 
number of firms are already ahead and catching up would demands adaptive, integrative, agile and sustainable supply chain capabilities that many firms have not yet demonstrated.

Overcoming these challenges is important, as future competitiveness and health of an organisation might influence other network partners through numerous collaborations. Accordingly, we maintained that there is no easy way to sustainable competitiveness, but business strategies should address overall organisation performance. The quality of workforce would be an important capability in capturing sustainability performance. The company should focus on the supply of skilled workers and leaders as well as developing multidisciplinary teams to create complex and sustainable products plus innovative business models.

It may also be important to address the current social and environmental risk related with supply chains. Here industry must work together to further promote and market the opportunities for training and education. However, there is also challenge of resource for employees training and upgrading of workforce in arears such as the development of sustainable energy sources. Even though, agility and sustainability practices such as knowledge transfer partnerships, strategy alliance, closer customer relationship, stakeholder's engagement, reducing environmental impact and promoting better quality of life inside and outside the company environment may go a long way in address these mismatches and this should be the focus of any future manufacturing.

\section{Conclusions and further research}

Several issues involved in agile manufacturing as a competitive strategy were discussed in this review. The evolution of manufacturing agility, attributes of agile manufacturing, the drivers of agile manufacturing, identification of the enabling competencies deployable for agile manufacturing as well as critique of agile manufacturing were presented.

Three conclusions emanate from this review. First, agile manufacturing is indispensable as a means of enhancing competitive advantage. This is in the light of unprecedented market instability, which manifests in several ways such as complex customer requirements, companies attempt to outdo themselves, shrinking product life cycles and sporadic customer shifts. In this regard, the emphasis which agile manufacturing places on responsive adaptation would counter the destabilising influence of competitive pressures on business performance outcomes. 
Secondly, what are the enabling competencies by which the negative impacts of market and competitive pressures can be neutralised? Five enabling competencies explored in this study as agility enablers were identified from a range of alternative practices in manufacturing competence building. The five agility enablers are transparent customisation, agile supply chains, intelligent automation, total employee empowerment and technology integration. Hence (and thirdly), the five agility enablers should be the building blocks for agile manufacturing design, but they would require joint deployment so that they create positive multiplier effects. As part of future research, there is the potential to look into: (i) further confirming the five agility enablers and their interactions; this can be operationalised in the form of framework and/or research propositions and hypotheses that could be further explored using for instance qualitative in-depth studies or surveys to validate them and see how they are applied and achieved in different contexts; (ii) demonstrating the magnitude of market pressures as a driver of agile manufacturing, and this is important as a means of identifying and justifying agile manufacturing enablers of competitive advantage; and (iii) looking into the importance of technology in particular as an enabler of agility given the recent focus on big data, blockchain, and Internet of Things.

\section{References}

Adeleye, E.O., Yusuf, Y.Y and Sivayoganathan, K., 2000. "Leanness, Agility and Manufacturing Performance in the UK." Proceedings of the $4^{\text {th }}$ International Conference on Managing Innovative Manufacturing, Aston Business School, Birmingham, July 17-19, 19-27.

Agarwal, A., Shankar, R. and Tiwari, M.K., 2006. "Modelling the Metrics of Lean, Agile and Leagile Supply Chain: An ANP-Based Approach.” European Journal of Operational Research, 173(1): 211-225.

Aggarwal, S., 1985. "Making Sense of Production Operations Systems." Harvard Business Review, Sept-Oct: 8-16.

Ahkioon, S., Bulgak, A.A. and Bektas, T., 2009. "Cellular Manufacturing Systems Design with Routing Flexibility, Machine Procurement, Production Planning and Dynamic System Reconfiguration.” International Journal of Production Research, 47(6): 1573-1600.

Ahmad, S., Schroeder, R.G. and Mallick, D.N., 2010. “The Relationship among Modularity, Functional Coordination, and Mass Customization: Implications for Competitiveness." European Journal of Innovation Management, 13(1): 46-61.

Aitken, J., Christopher, M. and Towill, D., 2002. "Understanding, Implementing and Exploiting Agility and Leanness." International journal of Logistics, 5(1): 59-74. 
Alfalla-Luque, R., Machuca, J.A. and Marin-Garcia, J.A., 2018. "Triple-A and Competitive Advantage a Supply Chains: Empirical Research in Developed Countries." International Journal of Production Economics, 203: 48-61.

Alford, D., Sackett, P. and Nelder, G., 2000. "Mass Customisation - An Automotive Perspective." International Journal of Production Economics, 65(1): 99-110.

Alhourani, F., 2016. "Cellular Manufacturing System Design Considering Machines Reliability and Parts Alternative Process Routings." International Journal of Production Research, 54(3): 846-863.

Almeida Marodin, G. and Saurin, T.A., 2015. "Managing Barriers to Lean Production Implementation: Context Matters." International Journal of Production Research, 53(13): 3947-3962.

Aqlan, F., and Al-Fandi, L., 2018. "Prioritizing Process Improvement Initiatives in Manufacturing Environments." International Journal of Production Economics 196: 261-268.

Arampantzi, C., Minis, I. and Dikas, G. (2018). “A Strategic Model for Exact Supply Chain Network Design and its Application to a Global Manufacturer", International Journal of Production Research, 2018(1): 127. DOI: $10.1080 / 00207543.2018 .1489155$

Aravind Raj, S., Sudheer, A., Vinodh, S. and Anand, G., 2013. "A Mathematical Model to Evaluate the Role of Agility Enablers and Criteria in a Manufacturing Environment." International journal of production research, 51(19): 5971-5984.

Arrais-Castro, A., Varela, M. L. R., Putnik, G. D., Ribeiro, R. A., Machado, J. and Ferreira, L. (2018). "Collaborative Framework for Virtual Organisation Synthesis Based on a Dynamic Multi-Criteria Decision Model", International Journal of Computer Integrated Manufacturing, 31(9): 857-868.

Barlow, J., Childerhouse, P., Gann, D., Hong-Minh, S., Naim, M. and Ozaki, R., 2003. “Choice and Delivery in Housebuilding: Lessons from Japan for UK Housebuilders.” Building research \& information, 31(2): 134-145.

Bartezzaghi, E., 1999. “The Evolution of Production Models: Is a New Paradigm Emerging?” International Journal of Operations and Production Management, 19 (2): 229-250.

Basu, D., and Das, D. 2017. "Profitability in India's Organized Manufacturing Sector: The Role of Technology, Distribution and Demand." Cambridge Journal of Economics 42(1):137-153.

Bello-Pintado, A., García Marco, T. and Zouaghi, F. 2018. "Product/Process Definition, Technology Adoption and Workforce Qualification: Impact on Performance", International Journal of Production Research, 2018 (1): 1-16. DOI: 10.1080/00207543.2018.1468096

Bhuiyan, N., Baghel, A. and Wilson, J., 2006. “A Sustainable Continuous Improvement Methodology at an Aerospace Company." International Journal of Productivity and Performance Management, 55(8): 671-687. 
Blome, C., Schoenherr, T. and Eckstein, D., 2014. “The Impact of Knowledge Transfer and Complexity on Supply Chain Flexibility: A Knowledge-Based View." International Journal of Production Economics, 147: 307-316.

Blome, C., Schoenherr, T. and Rexhausen, D., 2013. "Antecedents and Enablers Of Supply Chain Agility And Its Effect On Performance: A Dynamic Capabilities Perspective." International Journal of Production Research, 51(4): 1295-1318.

Boardman, J.T. and Clegg, B.T., 2001. "Structured Engagement in the Extended Enterprise." International Journal of Operations \& Production Management, 21(5/6): 795-811.

Bodine, W.E., 1998. “Making Agile Assembly Profitable.” Manufacturing Engineering, 121 (4): 60-68.

Booth, C.L and Harmer, M.P., 1995. "Agility, the Future for Ceramic Manufacturing." Ceramic Engineering Science Proceedings, 16 (1): 220-225.

Borges, L.A. and Tan, K.H., 2017. "Incorporating Human Factors into the AAMT Selection: A Framework and Process." International Journal of Production Research, 55(5):1459-1470.

Bortolotti, T., Boscari, S. and Danese, P., 2015. "Successful Lean Implementation: Organizational Culture and Soft Lean Practices." International Journal of Production Economics, 160: 182-201.

Braunscheidel, M.J. and Suresh, N.C., 2009. “The Organizational Antecedents of a Firm's Supply Chain Agility for Risk Mitigation and Response." Journal of operations Management, 27(2): 119-140.

Brown, S. and Bessant, J., 2003. "The Manufacturing Strategy-Capabilities Links in Mass Customisation and Agile Manufacturing - An Exploratory Study." International Journal of Operations \& Production Management, 23(7): 707-730.

Browne, J. Sackett, J., and Wortmann J., 1995. "Future Manufacturing Systems - Towards the Extended Enterprise." Computers in Industry, 25: 235-254.

Brussels, H. V., Bongaerts, L., Valckenaers, P., and Ginderachter, T. V., 1999. “A Conceptual Framework for Holonic Manufacturing: Identification of Manufacturing Holons." Journal of Manufacturing Systems, 18 (1): 35-52.

Brusset, X., 2016. “Does Supply Chain Visibility Enhance Agility?” International Journal of Production Economics, 171: 46-59.

Caggiano, A. and Teti, R., 2018. "Digital Factory Technologies for Robotic Automation and Enhanced Manufacturing Cell Design.” Cogent Engineering, 5(1): 1426676.

Cai, S., Goh, M., de Souza, R. and Li, G., 2013. "Knowledge Sharing in Collaborative Supply Chains: Twin Effects of Trust and Power.” International Journal of Production Research, 51(7): 2060-2076.

Camarinha-Matos, L. M., Macedo, P., Oliveira, A. I., Ferrada, F., \& Afsarmanesh, H. 2013. "Collaborative Environment for Service-Enhanced Products." In Industrial Informatics, 2013: 374-379. Available at: 
https://ieeexplore.ieee.org/stamp/stamp.jsp?tp=\&arnumber=6622913 (Accessed: 23 August 2018).

Castellano, J. F., Klein, D. and Roehm, H. A., 1999. "Mini-Companies: The Next Generation of Employee Empowerment." Management Accounting, 9: 22-30.

Chambers, S. and Nicholson, J., 2000. "Cellular Manufacturing and Marketing Strategy in the UK Small and Medium Enterprises." International Journal of Manufacturing Technology and Management, 1 (4/5): 428-443.

Chandra, C. and Kumar, S., 2000. "Supply Chain Management in Theory and Practice: A Passing Fad or a Fundamental Change?” Industrial Management \& Data Systems, 100(3):100-114.

Chen, H., Chiang, R. H. L. and Storey, V. C. (2012). "Business Intelligence and Analytics: From Big Data to Big Impact", MIS Quarterly: Management Information Systems, 36(4):1165-1188.

Chen, I.J. and Paulraj, A., 2004. "Towards A Theory of Supply Chain Management: The Constructs and Measurements." Journal of operations management, 22(2):119-150.

Chiang, C.Y., Kocabasoglu-Hillmer, C. and Suresh, N., 2012. "An Empirical Investigation of the Impact of Strategic Sourcing and Flexibility on Firm's Supply Chain Agility." International Journal of Operations \& Production Management, 32(1): 49-78.

Choi, T.M. and Guo, S., 2018. "Responsive Supply in Fashion Mass Customisation Systems with Consumer Returns." International Journal of Production Research, 56(10): 3409-3422.

Christopher, M. (2016). Logistics \& supply chain management. Harlow, England: Pearson Education.

Christopher, M. and Towill, D., 2001. "An Integrated Model for Agile Supply Chains.” International Journal of Physical Distribution and Logistics Management, 31 (4): 235-246.

Christopher, M., 2000. “The Agile Supply Chain: Competing in Volatile Markets.” Industrial marketing management, 29(1): 37-44.

Ciccullo, F., Pero, M., Caridi, M., Gosling, J. and Purvis, L. (2017). "Integrating the Environmental and Social Sustainability Pillars into the Lean and Agile Supply Chain Management Paradigms: A Literature Review and Future Research Directions", Journal of Cleaner Production; Journal of Cleaner Production, 172: 2336-2350.

Coronado Mondragon, A. E. and Coronado Mondragon, C. E. (2018). "Managing Complex, Modular Products: How Technological Uncertainty Affects the Role of Systems Integrators in the Automotive Supply Chain", International Journal of Production Research, 2018(1): 1-16. DOI: 10.1080/00207543.2018.1424362

Cozzarin, B.P., 2016. "Advanced Technology, Innovation, Wages and Productivity in the Canadian Manufacturing Sector." Applied Economics Letters, 23(4): 243-249. 
Da Silveira, G., Borenstein, D. and Fogliatto, F.S., 2001. "Mass Customization: Literature Review and Research Directions.” International journal of production economics, 72(1): 1-13.

Dailami, F. and Redford, A., 1998. "Twin Arm Manipulator for the Assembly of Large Products." Assembly Automation, 18 (1): 48-56.

Davenport T. H., 1998. "Putting the Enterprise into the Enterprise System." Harvard Business Review, 76 (4): 121-131.

De Groote, S.E. and Marx, T.G., 2013. “'The Impact of IT on Supply Chain Agility and Firm Performance: An Empirical Investigation." International Journal of Information Management, 33(6): 909-916.

Deitz, D., 1995. “Customer Driven Product Delivery.” Mechanical Engineering, 117 (12): 72-74.

Dowlatshahi, S., and Q. Cao. 2006. "The Relationships Among Virtual Enterprise, Information Technology, And Business Performance in Agile Manufacturing: An Industry Perspective.” European Journal of Operational Research, 174 (2): 835-860.

Dubey, R. and Gunasekaran, A., 2015. “Agile Manufacturing: Framework and its Empirical Validation.” The International Journal of Advanced Manufacturing Technology, 76(9-12): 2147-2157.

Dubey, R., Altay, N., Gunasekaran, A., Blome, C., Papadopoulos, T. and Childe, S.J., 2018. “Supply Chain Agility, Adaptability and Alignment: Empirical Evidence from the Indian Auto Components Industry." International Journal of Operations \& Production Management, 38(1): 129-148.

Duray, R., 2002. "Mass Customization Origins: Mass or Custom Manufacturing?” International Journal of Operations \& Production Management, 22(3): 314-328.

Dwayne Whitten, G., Green Jr, K.W. and Zelbst, P.J., 2012. "Triple-A Supply Chain Performance". International Journal of Operations \& Production Management, 32(1): 28-48.

Dyer, J.H. and Singh, H., 1998. "The Relational View: Cooperative Strategy and Sources of Interorganisational Competitive Advantage." Academy of management review, 23(4): 660-679.

Eckstein, D., Goellner, M., Blome, C. and Henke, M., 2015. “The Performance Impact of Supply Chain Agility and Supply Chain Adaptability: The Moderating Effect of Product Complexity." International Journal of Production Research, 53(10): 3028-3046.

Edwards, D., 1996. "Practical Guidelines for Lean Manufacturing Equipment." Production and Inventory Management Journal, 37(2): 51-55.

Esmail, K.K. and Saggu, J., 1996. “Agile Manufacturing: A Changing Paradigm.” Manufacturing Engineer, 75 (6): 285-288.

Fawcett, S.E. and Myers M.B., 2001. "Product and Employee Development in Advanced Manufacturing: Implementation and Impact." International Journal of Production Research, 39 (1), 65-79. 
Fliedner, G. and Vokurka, R.J., 1997. “Agility: Competitive Weapon of the 1990s And Beyond?” Production and Inventory Management Journal, 38(3): 1-19.

Forsythe, C. and Ashby, M.R., 1996. "Human Factors in Agile Manufacturing." Ergonomics in Design, 4(1): $15-21$.

Forsythe, C., 1997. "Human Factors in Agile Manufacturing: A Brief Overview with Emphasis on Communications and Information Infrastructure." Human factors and ergonomics in manufacturing, 7 (1): 3-10.

Forza, C., 1996. "Work Organisation in Lean Production and Traditional Plants." International Journal of Operations and Production Management, 16 (2): 42-62.

Fridgen, G., Stepanek, C. and Wolf, T., 2015. "Investigation of Exogenous Shocks in Complex Supply Networks-A Modular Petri Net Approach.” International Journal of Production Research, 53(5): 13871408.

Gadient, A.J., Hines, L.E., Welsh, J. and Schwalb, A.P., 1997. “Agility Through Information Sharing: Results Achieved in a Production Setting." Concurrent Engineering: Research and Applications, 5 (2): 101 111.

Gagnon, S., 1999. "Resource-Based Competition and the New Operations Strategy." International Journal of Operations and Production Management, 19 (2): 125-138.

Ghobakhloo, M., Hong, T.S. and Standing, C., 2014. "Business-to-Business Electronic Commerce Success: A Supply Network Perspective." Journal of Organizational Computing and Electronic Commerce, 24(4): 312-341.

Gilmore, J.H. and Pine II, B.J., 1997. “The Art of Customisation.” Harvard Business Review, Jan-Feb.: 99-101.

Gligor, D. M. and Holcomb, M., 2014. "The Road to Supply Chain Agility: An RBV Perspective on the Role of Logistics Capabilities.” The International Journal of Logistics Management, 25(1): 160-179.

Gligor, D.M. and Holcomb, M.C., 2012. "Antecedents and Consequences of Supply Chain Agility: Establishing the Link to Firm Performance.” Journal of Business Logistics, 33(4): 295-308.

Gligor, D.M., Holcomb, M.C. and Feizabadi, J. 2016. “An Exploration of The Strategic Antecedents of Firm Supply Chain Agility: The Role of a Firm's Orientations.” International Journal of Production Economics, 179: 24-34.

Goldman, S.L. and Nagel, R.N., 1992. "Management, Technology and Agility: The Emergence of a New Era in Manufacturing.” International Journal of Technology Management, 18 (1/ 2): 18-38.

Goldman, S.L., Nagel, R. N. and Preiss, K., 1995. "Agile Competitors and Virtual Organisations." Manufacturing Review, 8 (1): 59-67. 
Goldsby, T.J., Griffis, S.E. and Roath, A.S., 2006. "Modeling Lean, Agile, and Leagile Supply Chain Strategies." Journal of Business Logistics, 27(1): 57-80.

Gordon, J. and Sohal, A.S., 2001. “Assessing Manufacturing Plant Competitiveness. An Empirical Field Study." International Journal of Operations and Production Management, 21 (1/2): 233-253.

Gould, P., 1997. What is Agility? Manufacturing Engineer, 76 (1): 28-31.

Groover, M. P. (2007). Automation, Production Systems, and Computer-integrated Manufacturing. 3rd ed, New York: Prentice Hall Press.

Gunasekaran, A. and Ngai, E.W., 2004. "Information Systems in Supply Chain Integration and Management." European Journal of Operational Research, 159(2): 269-295.

Gunasekaran, A. and Yusuf, Y.Y., 2002. "Agile Manufacturing: A Taxonomy of Strategic and Technological Imperatives.” International Journal of Production Research, 40(6): 1357-1385.

Gunasekaran, A., 1998. “Agile Manufacturing: Enablers and an Implementation Framework." International Journal of Production Research, 36 (5): 1223-1247.

Gunasekaran, A., 1999. “Agile Manufacturing: A Framework for Research and Development.” International Journal of Production Economics, 62: 87-105.

Gunasekaran, A., Subramanian, N. and Papadopoulos, T., 2017. "Information Technology for Competitive Advantage Within Logistics and Supply Chains: A Review." Transportation Research Part E: Logistics and Transportation Review, 99: 14-33.

Gunasekaran, A., Yusuf, Y.Y., Adeleye, E.O. and Papadopoulos, T., 2018. “Agile Manufacturing Practices: The Role of Big Data and Business Analytics with Multiple Case Studies." International Journal of Production Research, 56(1-2): 385-397.

Gunneson, A. O., 1997. Transitioning to Agility. Creating the 21st. Century Enterprise. New York: Addison Wesley Publishing Company.

Hallgren, M., and Olhanger, J. 2009. "Lean and Agile Manufacturing: External and Internal Drivers and Performance Outcomes." International Journal of Operations \& Production Management, 29 (10): 976999.

Hamel, G. and Prahalad, C. K., 1994. "Competing for The Future.” Harvard Business Review, Jul-Aug: 122128.

Han, J.H., Wang, Y. and Naim, M., 2017. "Reconceptualization of Information Technology Flexibility for Supply Chain Management: An Empirical Study.” International Journal of Production Economics, 187: 196-215.

Harrison, A. and Storey, J., 1996. "New Wave Manufacturing Strategies - Operational, Organisational and Human Dimensions." International Journal of Operations and Production Management, 16 (2): 63-76. 
Harrison, A., R. I. Van Hoek and Skipworth Heather (2014). Logistics Management and Strategy: Competing through the Supply Chain. London; Pearson Education.

Hasani, A., Zegordi, S.H. and Nikbakhsh, E., 2012. "Robust Closed-Loop Supply Chain Network Design for Perishable Goods in Agile Manufacturing under Uncertainty." International Journal of Production Research, 50(16): 4649-4669.

Henry, C., 1998. "The Human Factor in Advanced Manufacturing Technology Utilisation: An Empirical Analysis." International Journal of Operations and Production Management, 18 (1): 87-106.

Hines, P., Taylor, D. and Walsh, A. 2018. “The Lean journey: have we got it wrong?”, Total Quality Management \& Business Excellence, 14 (1): 1-18. DOI: 10.1080/14783363.2018.1429258

Hoek, R. I., Harrison, A and Christopher, M., 2001. "Measuring Agile Capabilities in the Supply Chain." International Journal of Operations and Production Management, 21 (1/2): 126-147.

Hu, S.J., Zhu, X., Wang, H. and Koren, Y., 2008. "Product Variety and Manufacturing Complexity in Assembly Systems and Supply Chains." CIRP Annals-Manufacturing Technology, 57(1): 45-48.

Huang, X., Kristal, M.M. and Schroeder, R.G., 2008. "Linking Learning and Effective Process Implementation to Mass Customization Capability.” Journal of Operations Management, 26(6): 714729.

Iakymenko, N., Alfnes, E. and Thomassen, M.K., 2016. "A Differentiated Approach for Justification of Advanced Manufacturing Technologies." Advances in Manufacturing, 4(3): 257-267.

Inman, R. A., Sale, R. S., Green Jr., K. W., and Whitten, D. 2011. "Agile Manufacturing: Relation to JIT, Operational Performance and Firm Performance." Journal of Operations Management 29(4): 343-355.

Inman, R.R. and Blumenfeld, D.E., 2014. "Product Complexity and Supply Chain Design." International Journal of Production Research, 52(7): 1956-1969.

Iqbal, T., Huq, F. and Bhutta, M. K. 2018. “Agile Manufacturing Relationship Building with TQM, JIT, and Firm Performance: An Exploratory Study in Apparel Export Industry of Pakistan', International Journal of Production Economics; International Journal of Production Economics, 203 (1): 24-37. DOI: 10.1016/j.ijpe.2018.05.033

Jacobs, M.A., 2013. Complexity: “Toward an Empirical Measure.” Technovation, 33(4-5): 111-118.

Jasti, N.V.K. and Kodali, R., 2015. “A Critical Review of Lean Supply Chain Management Frameworks: Proposed Framework.” Production Planning \& Control, 26(13): 1051-1068.

Jayaram, J. and Pathak, S., 2013. "A Holistic View of Knowledge Integration in Collaborative Supply Chains." International Journal of Production Research, 51(7): 1958-1972. 
Jayaraman, V., Ross, A.D. and Agarwal, A., 2008. "Role of Information Technology and Collaboration in Reverse Logistics Supply Chains." International Journal of Logistics: Research and Applications, 11(6): 409-425.

Jitpaiboon, T., Dobrzykowski, D.D., Ragu-Nathan, T.S. and Vonderembse, M.A., 2013. "Unpacking IT Use and Integration for Mass Customisation: A Service-Dominant Logic View.” International Journal of Production Research, 51(8), pp.2527-2547.

Jonsson, P., and Mattsson, S.-A. 2008. "Inventory Management Practices and Their Implications on Perceived Planning Performance." International Journal of Production Research 46(7): 1787-1812.

Kache, F. and Seuring, S., 2017. "Challenges and Opportunities of Digital Information at the Intersection of Big Data Analytics and Supply Chain Management." International Journal of Operations \& Production Management, 37(1): 10-36.

Kang, H.S., Lee, J.Y., Choi, S., Kim, H., Park, J.H., Son, J.Y., Kim, B.H. and Do Noh, S., 2016. "Smart Manufacturing: Past Research, Present Findings, and Future Directions." International Journal of Precision Engineering and Manufacturing-Green Technology, 3(1): 111-128.

Karlsson, C., \& Åhlström, P. (1996). “The Difficult Path to Lean Product Development.” Journal of Product Innovation Management: An International Publication of the Product Development \& Management Association, 13(4): 283-295.

Karlsson, C., 1996. "Radically New Production Systems." International Journal of Operations and Production Management, 16 (11): 8-19.

Kehoe, D. and Boughton, N., 2001. "Internet Based Supply Chain Management. A Classification of Approaches to Manufacturing Planning and Control." International Journal of Operations and Production Management, 21 (4), 516-524.

Khanchanapong, T., Prajogo, D., Sohal, A.S., Cooper, B.K., Yeung, A.C. and Cheng, T.C.E., 2014. “The Unique and Complementary Effects of Manufacturing Technologies and Lean Practices on Manufacturing Operational Performance.” International Journal of Production Economics, 153: 191-203.

Kidd, P.T., 1994. Agile Manufacturing. Forging new frontiers. Workinghan, England: Addison Wesley Publishing Company.

Kim, M. and Chai, S., 2017. "The Impact of Supplier Innovativeness, Information Sharing and Strategic Sourcing on Improving Supply Chain Agility: Global Supply Chain Perspective.” International Journal of Production Economics, 187: 42-52.

Kirk, S. and Tebaldi, E., 1997. "Design of Robotic Facilities for Agile Automobile Engineering.” Industrial Robot, 24 (1): 72-77. 
Kisperska-Moron, D. and De Haan, J., 2011. "Improving Supply Chain Performance to Satisfy Final Customers: "Leagile" Experiences of a Polish Distributor." International Journal of Production Economics, 133(1): 127-134.

Kotha, S. and Swamidass, P.M., 2000. "Strategy, Advanced Manufacturing Technology and Performance: Empirical Evidence from US Manufacturing Firms." Journal of Operations Management, 18(3): 257277.

Kusiak, A. and He, D.W., 1997. "Design for Agile Assembly: An Operational Perspective." International Journal of Production Research, 35 (1): 157-178.

Kusiak, A., 2018. “Smart Manufacturing.” International Journal of Production Research, 56(1-2): 508-517.

Lai, F., Zhang, M., Lee, D.M. and Zhao, X., 2012. "The Impact of Supply Chain Integration on Mass Customization Capability: An Extended Resource-Based View." IEEE Transactions on Engineering Management, 59(3): 443-456.

Lampel, J. and Mintzberg, H., 1996. “Customizing Customization. Sloan Management Review.” fall, 38(1): 21-30.

Lapoule, P. and Colla, E., 2016. “The Multi-Channel Impact on the Sales Forces Management.” International Journal of Retail \& Distribution Management, 44(3): 248-265.

Lau, H.Y., Mak, K.L. and Ngan, M.C.C., 2002. “An Intelligent Robotic Framework for the Execution of Contact Assembly Tasks." International Journal of Computer Integrated Manufacturing, 15(6): 511-525.

Lee, G.H., 1998. "Design of Components and Manufacturing Systems for Agile Manufacturing." International Journal of Production Research, 36 (4): 1023-1044.

Lee, H.L., 2004. “The Triple-A Supply Chain.” Harvard business review, 82(10): 102-113.

Lee, S.K., Kuo, H.C., Balkir, N.H., and Ozsoyoglu, G., 1997. “A Database Server Architecture for Agile Manufacturing." Proceedings - IEEE International Conference on Robotics and Automation, IEEE Piscataway, NJ, 4: 3048-3053.

Lee, W.B. and Lau, H.C., 1999. "Factory on Demand: The Shaping of an Agile Production Network." International Journal of Agile Management Systems, 1 (2): 83-87.

Lehoux, N., D’Amours, S. and Langevin, A., 2014. "Inter-Firm Collaborations and Supply Chain Coordination: Review of Key Elements and Case Study." Production Planning \& Control, 25(10): 858872.

Leite, M. and Braz, V., 2016. "Agile Manufacturing Practices for New Product Development: Industrial Case Studies.” Journal of Manufacturing Technology Management, 27(4): 560-576.

Lewis, M.A., 2000. "Lean Production and Sustainable Competitive Advantage." International Journal of Operations and Production Management, 20 (8): 959-978. 
Li, X., Chung, C., Goldsby, T.J. and Holsapple, C.W., 2008. "A Unified Model of Supply Chain Agility: The Work-Design Perspective." The International Journal of Logistics Management, 19(3), pp.408-435.

Lin, C.T., Chiu, H. and Chu, P.Y., 2006. “Agility Index in The Supply Chain.” International Journal of Production Economics, 100(2): 285-299.

Liu, G., Shah, R. and Schroeder, R.G., 2012. "The Relationships among Functional Integration, Mass Customisation, and Firm Performance." International Journal of Production Research, 50(3): 677-690.

Liu, H., Ke, W., Wei, K.K. and Hua, Z., 2013. “The Impact of IT Capabilities on Firm Performance: The Mediating Roles of Absorptive Capacity and Supply Chain Agility.” Decision Support Systems, 54(3): $1452-1462$.

MacDonald, E.F. and She, J., 2015. "Seven Cognitive Concepts for Successful Eco-Design.” Journal of Cleaner Production, 92: 23-36.

Macke, N., Rulhoff, S. and Stjepandic, J., 2016. Advances in Smart Manufacturing Change Management. In Borsato, M., (ed) Transdisciplinary Engineering: Crossing Boundaries: Netherlands: (Vol. 4). IOS Pres: 318-327

Marodin, G. A., Frank, A. G., Tortorella, G. L. and Fetterman, D. C. 2017. "Lean Production and Operational Performance in the Brazilian Automotive Supply Chain”, Total Quality Management and Business Excellence, 53 (14): 1-16. DOI: 10.1080/14783363.2017.1308221

Marodin, G.A. and Saurin, T.A., 2013. "Implementing Lean Production Systems: Research Areas and Opportunities for Future Studies.” International Journal of Production Research, 51(22): 6663-6680.

Marodin, G. A., and T. A. Saurin. 2015. "Managing Barriers to Lean Production Implementation: Context Matters." International Journal of Production Research 53 (13): 3947-3962.

Martinez-Sanchez, A. and Lahoz-Leo, F., 2018. "Supply Chain Agility: A Mediator for Absorptive Capacity." Baltic Journal of Management, 13(2): 264-278.

Maskell, B., 2001. “The Age of Agile Manufacturing." Supply Chain Management: An International Journal, 6 (1): 5-11.

Mason-Jones, R., Naylor, B. and Towill, D.R., 2000. "Lean, Agile or Leagile? Matching Your Supply Chain to the Marketplace." International Journal of Production Research, 38 (17): 4061-4070.

Matzler, K., Stieger, D. and Füller, J., 2011. "Consumer Confusion in Internet-Based Mass Customization: Testing a Network of Antecedents and Consequences." Journal of Consumer Policy, 34(2), pp.231247.

McMains, S. (2005). "Layered Manufacturing Technologies." Communications of the ACM, 48(6): 50-56.

Mentzer, J.T., DeWitt, W., Keebler, J.S., Min, S., Nix, N.W., Smith, C.D. and Zacharia, Z.G., 2001. "Defining Supply Chain Management." Journal of Business logistics, 22(2): 1-25. 
Merle, A., Chandon, J.L., Roux, E. and Alizon, F., 2010. "Perceived Value of the Mass-Customized Product and Mass Customization Experience for Individual Consumers." Production and Operations Management, 19(5): 503-514.

Mikkola, J. H. and Skjøtt-Larsen, T., 2004. "Supply-Chain Integration: Implications for Mass Customization, Modularization and Postponement Strategies." Production Planning \& Control, 15(4): 352-361.

Mo, J.P. and Cook, M., 2018. "Quantitative Lifecycle Risk Analysis of the Development of a Just-In-Time Transportation Network System.” Advanced Engineering Informatics, 36: 76-85.

Molina, A., Rodriguez, C.A., Ahuett, H., Cortés, J.A., Ramírez, M., Jiménez, G. and Martinez, S., 2005. "Next-Generation Manufacturing Systems: Key Research Issues in Developing and Integrating Reconfigurable and Intelligent Machines." International Journal of Computer Integrated Manufacturing, 18(7): 525-536.

Monostori, L., Kádár, B., Bauernhansl, T., Kondoh, S., Kumara, S., Reinhart, G., Sauer, O., Schuh, G., Sihn, W. and Ueda, K., 2016. "Cyber-Physical Systems in Manufacturing." CIRP Annals, 65(2): 621641.

Mountney, S.L., Gao, J.X. and Wiseall, S., 2007. "A Knowledge System to Support Manufacturing Knowledge During Preliminary Design.” International Journal of Production Research, 45(7): 1521-1537.

Naim, M.M. and Gosling, J., 2011. “On Leanness, Agility and Leagile Supply Chains.” International Journal of Production Economics, 131(1): 342-354.

Narasimhan, R., Swink, M. and Kim, S.W., 2006. "Disentangling Leanness and Agility: An Empirical Investigation." Journal of operations management, 24(5): 440-457.

Naylor, J.B., Naim, M.M. and Berry, D., 1999. "Leagility: Interfacing the Lean and Agile Manufacturing Paradigm in the Total Supply Chain.” International Journal of Production Economics, 62: 107-18.

Netland, T.H., 2016. "Critical Success Factors for Implementing Lean Production: The Effect of Contingencies." International Journal of Production Research, 54(8): 2433-2448.

Oliver, N., Delbridge, R. and Lowe, J., 1996. “The European Auto Components Industry: Manufacturing Performance and Practice." International Journal of Production and Operations Management, 16 (11): 8597.

Ong, S.K., Lin, Q. and Nee, A.Y.C., 2006. "Web-Based Configuration Design System for Product Customization." International Journal of Production Research, 44(2): 351-382.

Pallari, J. H., Dalgarno, K. W., \& Woodburn, J. (2010). "Mass Customization of Foot Orthoses for Rheumatoid Arthritis using Selective Laser Sintering." IEEE Transactions on Biomedical Engineering, 57(7): 1750-1756. 
Paranitharan, K.P. and Jeyathilagar, D., 2017. "An Empirical Validation of Integrated Manufacturing Business Excellence Model.” The International Journal of Advanced Manufacturing Technology, 92(5-8): 2569-2591.

Peng, D. X., G. Liu, and G. R. Heim. 2011. "Impacts of Information Technology on Mass Customization Capability of Manufacturing Plants." International Journal of Operations \& Production Management 31 (10): 1022-1047.

Perry, M. and Sohal, A. S., 2001. "Effective Quick Response Practices in a Supply Chain Partnership: An Australian Case Study." International Journal of Operations and Production Management, 21 (5/6): 840854.

Phaithoonbuathong, P., Monfared, R., Kirkham, T., Harrison, R. and West, A., 2010. “Web Services-Based Automation for the Control and Monitoring of Production Systems." International Journal of Computer Integrated Manufacturing, 23(2): 126-145.

Pillai, V.M. and Subbarao, K., 2008. “A Robust Cellular Manufacturing System Design for Dynamic Part Population using a Genetic Algorithm.” International Journal of Production Research, 46(18): 5191-5210.

Pine II, B.J. and Davis, S., 1993. Mass Customisation: The New Frontier in Business Competition. Boston, Mass: Harvard Business School Press.

Pine II, B.J., Victor B. and Boynton A C., 1993. "Making Mass Customisation Work." Harvard Business Review, Sept.-Oct.: 109-119.

Pinochet, A., Matsubara, Y. and Nagamachi, M., 1996. "Construction of A Knowledge-Based System for Diagnosing the Socio-Technical Integration in Advanced Manufacturing Technologies." The International Journal of Human Factors in Manufacturing, 6 (4): 323-349.

Plonka, F.E., 1997. "Developing a Lean and Agile Work Force." Human Factors and Ergonomics in Manufacturing \& Service Industries, 7(1): 11-20.

Potdar, P.K., Routroy, S. and Behera, A., 2017a. “Addressing the Agile Manufacturing Impediments using Interpretive Structural Modelling." Materials Today: Proceedings, 4(2): 1744-1751.

Potdar, P.K., Routroy, S. and Behera, A., 2017b. “Agile Manufacturing: A Systematic Review of Literature and Implications for Future Research.” Benchmarking: An International Journal, 24(7): 2022-2048.

Potdar, P.K., Routroy, S. and Behera, A., 2017c. "Analysing the Agile Manufacturing Barriers using Fuzzy DEMATEL.” Benchmarking: An International Journal, 24(7): 1912-1936.

Power, D.J., Sohal, A.S. and Rahman, S., 2001. "Critical Success Factors in Agile Supply Chain Management. An Empirical Study." International Journal of Physical Distribution and Logistics Management, 31 (4): 247-265. 
Prater, E., Biehl, M. and Smith, M. A., 2001. "International Supply Chain Agility. Trade-offs Between Flexibility and Uncertainty." International Journal of Operations and Production Management, 21 (5/6): 823-839.

Pullan, T.T., Bhasi, M. and Madhu, G., 2010. "Application of Concurrent Engineering in Manufacturing Industry." International Journal of Computer Integrated Manufacturing, 23(5): 425-440.

Qin, R. and Nembhard, D.A., 2010. "Workforce Agility for Stochastically Diffused Conditions-A Real Options Perspective." International Journal of Production Economics, 125(2): 324-334.

Quinn J. B., 1992. Intelligent Enterprise. New York: The Free Press.

Quintana, R., 1998. "A Production Methodology for Agile Manufacturing in a High Turnover Environment." International Journal of Operations and Production Management, 1998, 18(5): 452-470.

Ramesh, G. and Devadasan, S.R., 2007. "Literature Review on the Agile Manufacturing Criteria." Journal of Manufacturing Technology Management, 18(2): 182-201.

Ramesh, R., Jyothirmai, S. and Lavanya, K., 2013. "Intelligent Automation of Design and Manufacturing in Machine Tools Using an Open Architecture Motion Controller." Journal of Manufacturing Systems, 32(1): 248-259.

Ren, J., Yusuf, Y.Y. and Burns, N.D., 2003. "The Effects of Agile Attributes on Competitive Priorities: A Neural Network Approach.” Integrated Manufacturing Systems, 14(6): 489-497.

Renna, P. and Ambrico, M., 2015. "Design and Reconfiguration Models for Dynamic Cellular Manufacturing to Handle Market Changes." International Journal of Computer Integrated Manufacturing, 28(2): 170-186.

Routroy, S., Potdar, P.K. and Shankar, A., 2015. "Measurement of Manufacturing Agility: A Case Study." Measuring Business Excellence, 19(2): 1-22.

Rungtusanatham, M.J. and Salvador, F., 2008. "From Mass Production to Mass Customization: Hindrance Factors, Structural Inertia, and Transition Hazard.” Production and Operations Management, 17(3): 385396.

Saban, K., Mawhinney, J.R. and Drake, M.J., 2017. “An Integrated Approach to Managing Extended Supply Chain Networks.” Business Horizons, 60(5): 689-697.

Salvador, F., De Holan, P.M. and Piller, F., 2009. "Cracking the Code of Mass Customization.” MIT Sloan management review, 50(3): 71-78.

Salvador, F., Rungtusanatham, M., \& Forza, C. (2004). "Supply-Chain Configurations for Mass Customization." Production Planning \& Control, 15(4): 381-397.

Sanchez, L.M. and Nagi, R., 2001. "A Review of Agile Manufacturing Systems.” International Journal of Production Research, 39(16): 3561-3600. 
Saraph, J. and Sebastian, R., 1992. "Human Resource Strategies for Effective Introduction of Advanced Manufacturing Technologies." Production and Inventory Management Journal, 33 (1): 64-74.

Searcy, C., 2012. "Corporate Sustainability Performance Measurement Systems: A Review and Research Agenda." Journal of business ethics, 107(3): 239-253.

Shah, R. and Ward, P.T., 2007. "Defining and Developing Measures of Lean Production." Journal of operations management, 25(4): 785-805.

Shamsuzzoha, A. and Helo, P., 2018. "Virtual Supply Chain for Networked Business: Perspective of Collaborative Bill-of-Materials, Scheduling and Process Monitoring for Developing Innovative Product." International Journal of Computer Integrated Manufacturing, 31(6): 595-610.

Shariatzadeh, N., Lundholm, T., Lindberg, L. and Sivard, G., 2016. "Integration of Digital Factory with Smart Factory Based on Internet of Things." Procedia CIRP, 50: 512-517.

Sharifi, H. and Zhang, Z., 2001. "Agile Manufacturing in Practice. Application of a Methodology." International Journal of Operations and Production Management 21 (5/6): 772-794.

Sharp, J.M., Irani, Z. and Desai, S., 1999. "Working Towards Agile Manufacturing in the UK Industry." International Journal of production economics, 62(1-2): 155-169.

Shaw, N.E., Burgess, T.F., De Mattos, C. and Stec, L.Z., 2005. "Supply Chain Agility: The Influence of Industry Culture on Asset Capabilities Within Capital Intensive Industries.” International Journal of Production Research, 43(16): 3497-3516.

Sheridan, J.H., 1993. “Agile Manufacturing: Stepping Beyond Lean Production.” Industry Week, 19: 31-36.

Shiyas, C.R. and Madhusudanan Pillai, V., 2014. "Cellular Manufacturing System Design Using Grouping Efficacy-Based Genetic Algorithm.” International Journal of Production Research, 52(12): 3504-3517.

Shukla, M., Todorov, I. and Kapletia, D. (2018). "Application of Additive Manufacturing for Mass Customisation: Understanding the Interaction of Critical Barriers", Production Planning and Control, 8 (1): 1-12. DOI: $10.1080 / 09537287.2018 .1474395$

Sigala, M., 2006. "Mass Customisation Implementation Models and Customer Value in Mobile Phones Services: Preliminary Findings from Greece.” Managing Service Quality: An International Journal, 16(4): 395-420.

Silveira, G.J.C.D., Fogliatto, F.S. and Fendyur, A., 2016. "Demographics of Mass Customization: A Global Study of Manufacturing Plants.” Production, 26(1): 1-11

Sindhwani, R. and Malhotra, V., 2018. "An Integrated Approach for Implementation of Agile Manufacturing System in an Indian Manufacturing Industry." Benchmarking: An International Journal, 25(4): 1106-1120. 
Singh, P.J. and Power, D., 2014. "Innovative Knowledge Sharing, Supply Chain Integration and Firm Performance of Australian Manufacturing Firms." International Journal of Production Research, 52(21): 6416-6433.

Singletary, E.P. and Winchester, S.C., 1998. "Beyond Mass Production: Strategic Management Models for Competitive Manufacturing Transformation in the US Textile Industry." Journal of the Textile Institute, 89 Part 2 (1): 4-15.

Smit, J., Kreutzer, S., Moeller, C. and Carlberg, M., 2016. "Industry 4.0." Study for the ITRE Committee, Policy Department A: Economic and Scientific Policy, European Parliament, Brussels.

Sohal, A.S., Sarros, J., Schroder, R. and O'neill, P., 2006. "Adoption Framework for Advanced Manufacturing Technologies." International Journal of Production Research, 44(24): 5225-5246.

Soliman, F. and Youssef, M., 2001. "The Impact of some Recent Developments in E-Business on the Management of Next Generation Manufacturing." International Journal of Operations and Production Management, 21 (5/6): 538-564.

Soliman, F., Clegg, S., and Tantoush, T. 2001. "Critical Success Factors for Integration of CAD/CAM Systems with ERP Systems." International Journal of Operations and Production Management, 21 (5/6): 609-629.

Soni, G. and Kodali, R., 2016. "Interpretive Structural Modelling and Path Analysis for Proposed Framework of Lean Supply Chain in Indian Manufacturing Industry.” Journal of Industrial and Production Engineering, 33(8): 501-515.

Sousa, R. and Voss, C.A., 2008. "Contingency Research in Operations Management Practices.” Journal of Operations Management, 26(6): 697-713.

Spina, G. et al., 1996. "Strategically Flexible Production: The Multi-Focused Manufacturing Paradigm." International Journal of Operations and Production Management, 16 (11): 20-41.

Spira, J.S., 1993. Mass customization through training at Lutron Electronics. Planning Review, 21(4), pp.2324.

Squire, B., Readman, J., Brown, S. and Bessant, J., 2004. "Mass Customization: The Key to Customer Value?" Production Planning \& Control, 15(4): 459-471.

Stevenson, M. and Spring, M., 2007. "Flexibility from a Supply Chain Perspective: Definition and Review." International journal of operations \& production management, 27(7): 685-713.

Sumukadas, N. and Sawhney, R., 2004. "Workforce Agility through Employee Involvement." Iie Transactions, 36(10): 1011-1021.

Swafford, P.M., Ghosh, S. and Murthy, N., 2006. "The Antecedents of Supply Chain Agility of a Firm: Scale Development and Model Testing." Journal of Operations Management, 24(2):170-188. 
Swafford, P.M., Ghosh, S. and Murthy, N., 2008. “Achieving Supply Chain Agility through IT Integration and Flexibility." International Journal of Production Economics, 116(2): 288-297.

Tarafdar, M. and Qrunfleh, S., 2017. "Agile Supply Chain Strategy and Supply Chain Performance: Complementary Roles of Supply Chain Practices and Information Systems Capability for Agility." International Journal of Production Research, 55(4): 925-938.

Theorin, A., Bengtsson, K., Provost, J., Lieder, M., Johnsson, C., Lundholm, T. and Lennartson, B., 2017. “An Event-Driven Manufacturing Information System Architecture for Industry 4.0.” International Journal of Production Research, 55(5): 1297-1311.

Thilak, V. M. M., Devadasan, S. R. and Sivaram, N. M. 2015. "A Literature Review on the Progression of Agile Manufacturing Paradigm and its Scope of Application in Pump Industry", The Scientific World Journal, 2015 (1): 1-9. DOI: 10.1155/2015/297850

Thomke, S. and Reinertsein, D., 1998. “Agile Product Development: Managing Development Flexibility in Uncertain Environments." California Management Review, 41 (1): 8-30.

Tortorella, G.L., Marodin, G.A., Fogliatto, F.S. and Miorando, R., 2015. "Learning Organisation and Human Resources Management Practices: An Exploratory Research in Medium-Sized Enterprises Undergoing a Lean Implementation.” International Journal of Production Research, 53(13): 3989-4000.

Tracy 1994. The following is the full reference: Tracy M. J. 1994. "Achieving Agile Manufacturing in the Automotive Industry." Automotive Engineer, 102 (11): 19-24.

Trentin, A., Forza, C. and Perin, E., 2012. "Organisation Design Strategies for Mass Customisation: An Information-Processing-View Perspective.” International Journal of Production Research, 50(14): 38603877.

Tsanos, S. C., G. Zografos, K. and Harrison, A., 2014. "Developing A Conceptual Model for Examining the Supply Chain Relationships Between Behavioural Antecedents of Collaboration, Integration and Performance." The International Journal of Logistics Management, 25(3): 418-462.

Tse, Y.K., Zhang, M., Akhtar, P. and MacBryde, J., 2016. "Embracing Supply Chain Agility: An Investigation in The Electronics Industry." Supply Chain Management: An International Journal, 21(1): 140-156.

Tseng, C.P., Chang, M.L. and Chen, C.W., 2012. "Retracted: Human Factors of Knowledge Sharing Intention among Taiwanese Enterprises: A Preliminary Study." Human Factors and Ergonomics in Manufacturing \& Service Industries, 22(4): 328-339.

Tu, Q., Vonderembse, M.A. and Ragu-Nathan, T.S., 2001. “The Impact of Time-Based Manufacturing Practices on Mass Customization and Value to Customer." Journal of Operations management, 19(2): 201-217. 
Tu, Q., Vonderembse, M.A., Ragu-Nathan, T.S. and Ragu-Nathan, B., 2004. “Measuring Modularity-Based Manufacturing Practices and their Impact on Mass Customization Capability: A Customer-Driven Perspective." Decision Sciences, 35(2): 147-168.

Upton, D., 1995. "What Really Makes Factories Flexible?” Harvard Business Review, July-August: 74-84.

van Hoof, B. and Thiell, M., 2014. "Collaboration Capacity for Sustainable Supply Chain Management: Small and Medium-Sized Enterprises in Mexico.” Journal of Cleaner Production, 67: 239-248.

Van Riet, C., De Clerck, D. and Demeulemeester, E., 2015. "Lean Beyond Company Borders: Costs or Benefits?" (January 2015). Available at SSRN: https://ssrn.com/abstract $=2553850$ or http://dx.doi.org/10.2139/ssrn.2553850

Venkatraman, N. and Henderson, J.C., 1998. "Real Strategies for Virtual Organizing." Sloan management review, 40(1): 33-48.

Vinodh, S., Arvind, K.R. and Rajanayagam, D., 2011. "Development of Digital Product Catalogue for Enabling Agility in A Manufacturing Organisation.” Journal of Engineering, Design and Technology, 9(2): 143-156.

Vinodh, S., Madhyasta, U.R. and Praveen, T., 2012. "Scoring and Multi-Grade Fuzzy Assessment of Agility in an Indian Electric Automotive Car Manufacturing Organisation.” International Journal of Production Research, 50(3): 647-660.

Vinodh, S., Sundararaj, G., Devadasan, S.R., Kuttalingam, D. and Rajanayagam, D., 2010. “Amalgamation of Mass Customisation and Agile Manufacturing Concepts: The Theory and Implementation Study in an Electronics Switches Manufacturing Company." International Journal of Production Research, 48(7): 2141-2164.

Vokurka, R.J. and Fliedner, G., 1998. “The Journey Toward Agility.” Industrial Management and Data Systems, 98 (4): 165-171.

Wagner, S.M. and Silveira-Camargos, V., 2012. "Managing Risks in Just-In-Sequence Supply Networks: Exploratory Evidence from Automakers." IEEE Transactions on Engineering Management, 59(1): 5264.

Wallace, T.F., 1992. Customer Driven Strategy. Vermont, USA: Oliver Wright Publications, Incorporation.

Wang, Q., Wang, Z. and Zhao, X., 2015. "Strategic Orientations and Mass Customisation Capability: The Moderating Effect of Product Life Cycle.” International Journal of Production Research, 53(17): 52785295.

Warkentin, M. E., Sayeed, L. and Hightower, R., 1997. "Virtual Teams Versus Face-To Face Teams: An Exploratory Study of a Web-Based Conference System.” Decision Sciences, 28(4): 975-993.

Waters, T. F., 1996. Fundamentals of Manufacturing for Engineers. London: UCL Press. 
Wee, H.M. and Wu, S., 2009. "Lean Supply Chain and its Effect on Product Cost and Quality: A Case Study on Ford Motor Company.” Supply Chain Management: An International Journal, 14(5): 335-341.

White, R. E., Pearson J. N. and Wilson J R., 1999. "JIT Manufacturing: A Survey of Implementation in Small and Large US Manufacturing Companies.” Management Science, 45 (1): 1-15.

Willis, T.H., 1998. "Operational Competitive Requirements for the Twenty-First Century.” Industrial Management and Data Systems, 98 (2): 83-86.

Wu, K.J., Tseng, M.L., Chiu, A.S. and Lim, M.K., 2017. “Achieving Competitive Advantage Through Supply Chain Agility Under Uncertainty: A Novel Multi-Criteria Decision-Making Structure." International Journal of Production Economics, 190: 96-107.

Wu, X., Chu, C.H., Wang, Y. and Yan, W., 2006. "Concurrent Design of Cellular Manufacturing Systems: A Genetic Algorithm Approach.” International Journal of Production Research, 44(6): 1217-1241.

Yan, S.H. and Jiang, J., 1999. “Agile Concurrent Engineering.” Integrated Manufacturing Systems, 10(2): 103112 .

Yang, H. and Lee, G.H., 1996. "An Approach to Human-Centred CIM Based on Production Information System." The International Journal of Human Factors in Manufacturing, 6 (4): 349-363.

Yang, J., 2014. "Supply Chain Agility: Securing Performance for Chinese Manufacturers.” International Journal of Production Economics, 150: 104-113.

Yasin, M. and Wafa, M., 1996. “An Empirical Examination of Factors Influencing JIT Success.” International Journal of Operations and Production Management, 16 (1): 19-26.

Young, S.M., 1992. "A Framework for Successful Adoption and Performance of Japanese Manufacturing Practices in the United States." Academy of Management Review, 17(14): 677-700.

Youssef, M. A., 1992. "Getting to Know Advanced Manufacturing Technologies.” Industrial Engineering, 24 (2): $40-42$.

Yusuf, Y.Y., 1996. "The Extension of MRPII in Support of Integrated Manufacture." Unpublished PhD report. Department of Industrial Studies, University of Liverpool.

Yusuf, Y.Y., Adeleye, E.O. and Sivayoganathan, K., 2001. "Agile Supply Chain Capabilities: Emerging Patterns as a Determinant of Competitive Objectives." SPIE: Proceedings of the International Conference on Internet-based Enterprise Integration and Management, Boston, USA, September 3-5, 4566, 8-19.

Yusuf, Y.Y., Gunasekaran, A., Adeleye, E.O. and Sivayoganathan, K., 2004. "Agile Supply Chain Capabilities: Determinants of Competitive Objectives." European Journal of Operational Research, 159(2): 379-392. 
Yusuf, Y.Y., Gunasekaran, A., Musa, A., Dauda, M., El-Berishy, N.M. and Cang, S., 2014. “A Relational Study of Supply Chain Agility, Competitiveness and Business Performance in the Oil and Gas Industry." International Journal of Production Economics, 147: 531-543.

Yusuf, Y.Y., Sarhadi, M., and Gunasekaran, A., 1999. “Agile Manufacturing: The Drivers, Concepts and Attributes." International Journal of Production Economics, 62: 33-43.

Zammuto, R. and O'Connor, E., 1992. "Gaining Advanced Technologies Benefits." Academy of Management Review, 17 (4): 701-728.

Zhang, D.Z., 2011. “Towards Theory Building in Agile Manufacturing Strategies - Case Studies of an Agility Taxonomy." International Journal of Production Economics, 131(1): 303-312.

Zhang, H. and Zhang, D., 1995. "Concurrent Engineering: An Overview from Manufacturing Engineering Perspectives." Concurrent Engineering: Research and Applications, 3 (3): 221-234.

Zhang, L., Luo, Y., Tao, F., Li, B.H., Ren, L., Zhang, X., Guo, H., Cheng, Y., Hu, A. and Liu, Y., 2014. "Cloud Manufacturing: A New Manufacturing Paradigm.” Enterprise Information Systems, 8(2): 167187.

Zhang, M., Guo, H., Huo, B., Zhao, X., Huang, J., 2017a. "Linking Supply Chain Quality Integration with Mass Customization and Product Modularity." International Journal of Production Economics In Press, https://doi.org/10.1016/j.ijpe.2017.01.011

Zhang, M., Qi, Y. and Guo, H., 2017b. "Impacts of Intellectual Capital on Process Innovation and Mass Customisation Capability: Direct and Mediating Effects." International Journal of Production Research, 55(23): 6971-6983.

Zhang, M., Qi, Y., Zhao, X. and Duray, R., 2015. "Mass Customisation Systems: Complementarities and Performance Consequences." International Journal of Logistics Research and Applications, 18(6): 459-475. 